BENJAMIN SUTER

\title{
THE SCOPE OF RIGHTS OF APPEAL (NOT RECOURSE) FROM ARBITRATION AWARDS
}

\author{
LLM RESEARCH PAPER \\ LAWS 582: MASTERS LEGAL WRITING
}

FACULTY OF LAW

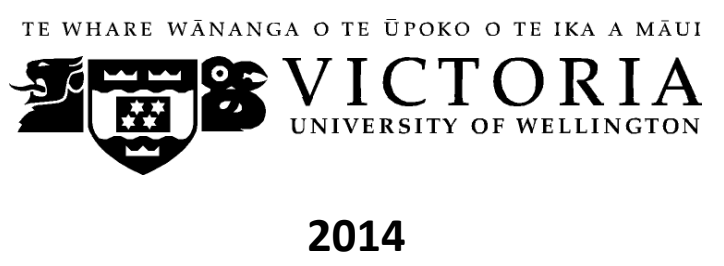




\section{Table of Contents}

I. INTRODUCTION

II. STATUTORY RIGHTS OF APPEAL

A. THE RULE OF THE MODEL LAW 5

B. FIRM STATUTES: UNITED STATES FEDERAL LAW

C. OPT-IN STATUTES 9

D. OPT-OUt STAtUTES

III. TREATMENT OF AGREEMENTS ON (EXPANDED) RIGHTS OF APPEAL 11
A. INVALIDITY OF SUCH AGREEMENTS
B. SEPARABILITY OF SUCH AGREEMENTS
C. SEVERABILITY OF SUCH AGREEMENTS

IV. DOCTRINES OF SEVERANCE AND PARTIAL NULLITY $\quad 17$

A. THE "BUT FOR"-TEST 17

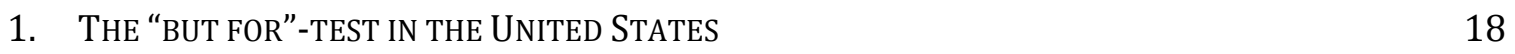

a) The pure "but for"-test $\quad 18$

b) The modified "but for"-test: Oklahoma and Alaska 19

2. THE "BUT FOR"-TEST IN SWITZERLAND 20

3. ThE "BUT FOR"-TEST In CONTINENTAl EUROPE 23

4. APPRAISAL OF THE “BUT FOR"-TEST 23

a) Rejection of the "but for"-test in the Commonwealth 23

b) Grounds for rejection of the "but for"-test 25

B. THE TEST EXAMINING THE EFFECT ON THE NATURE OF THE PROMISES 27

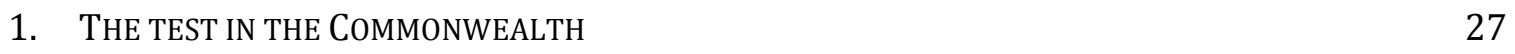

2. THE ENGLISH CASE OF HASHWANI V JiVRaJ 30

3. The NeW Zealand CaSe OF CARR V Gallaway CoOK Allan 31

4. Appraisal of THE COMMONWEalth test 34

C. THE TEST OF INTERCONNECTEDNESS OF THE VALID AND INVALID CLAUSES 36

1. THE BASIC TEST 36

2. THE CALIFORNIAN INQUIRY INTO THE INTERESTS OF JUSTICE 39

a) The original purpose of the inquiry 39

b) Recent case law on the inquiry $\quad 41$

c) Appraisal of the inquiry $\quad 43$

V. CONCLUSIONS 44 


\begin{abstract}
This paper examines the scope of rights of appeal from arbitration awards in New Zealand, Singapore, Switzerland, the United Kingdom and the United States.

In countries that have drafted their legislation after the UNCITRAL Model Law appeals are often excluded and only recourse based on very narrow grounds is available. While many countries are more permissive with regards to appeals than the Model Law in that they allow the parties to opt for more expansive review, none of the examined jurisdictions give the parties the right to opt for appeals on questions of law and fact.

In several cases parties have tried to expand the rights of appeal by agreement. Such agreements are deemed invalid in all jurisdictions. When examining whether the invalid clause renders the entire arbitration agreement invalid, courts in common law jurisdictions have applied the doctrine of severance in some variations. Civil law courts usually examine whether the parties would have concluded the contract without the invalid clause ("but for"-test).

This paper suggests that many of these tests are not suitable for arbitration agreements where the parties do not exchange considerations but rather promise one another exactly the same. The preferable approach is to combine the "but for"-test with a test that assesses if severance alters the nature of the agreement.
\end{abstract}

\title{
Word length
}

The text of this paper (excluding abstract, table of contents, footnotes and bibliography) comprises exactly 11,965 words.

\section{Subjects and Topics}

International arbitration agreements

Rights of appeal

Severability 


\section{Introduction}

It is a truth universally acknowledged that no one likes losing. ${ }^{1}$ Therefore, a party having lost a case will often seek to appeal. However, while the rules of litigation almost always provide for rights of appeal against a court of first instance's judgment, the situation is usually different with regard to arbitration awards.

In that regard, two possible ways to challenge an arbitral award need to be distinguished: The first one, which is referred to here as "appeal from arbitral awards", means an application to the courts to modify or correct the award for errors of facts and law. The second one will be referred to as "recourse" to the courts. Such recourse is defined here as an application to the courts to set aside an award based on selected grounds including lack of a valid arbitration agreement or of arbitrability, some severe procedural flaws or conflict with the public policy of the state of arbitration.

Most jurisdictions have taken an arbitration-friendly stance, favouring the finality of arbitral awards. Accordingly, rights of appeal from arbitration awards to state courts have been cut and rights of recourse have been restricted to the minimum necessary to preserve the integrity of both the judicial and the arbitral system. ${ }^{2}$

In the past years, cases became public in several countries where the parties deliberately chose to incorporate rights of appeal to state courts in their arbitration agreement, raising the question of how to deal with such agreements.

In the jurisdictions examined in this paper the appeal clauses are almost unanimously held as invalid. The question then becomes whether the appeal clause invalidates the remainder of the arbitration agreement as well. In common law jurisdictions this is a matter of the doctrine of severance; in civil law countries the doctrine of partial nullity applies.

The courts in the jurisdictions examined in this paper essentially all follow one of three different approaches. Switzerland and some jurisdictions in the United States apply

\footnotetext{
${ }^{1}$ See Nigel Blackaby and others Redfern and Hunter on International Arbitration (5th ed (student version), Oxford University Press, Oxford, 2009) at [10.01]; with apologies to Jane Austen.

${ }^{2}$ See Eric van Ginkel “Expanded' Judicial Review Revisited: Kyocera Overturns LaPine” 4 Pepp Disp Resol L J 47 at 50.
} 
an approach that inquires into whether the parties would have entered into the agreement without the invalid clause ("but for"-test). The approach preferred in the Commonwealth looks at the contract that the parties have agreed on and permits severance if the agreement will still be substantially the same without the clause to be severed. The third approach, which is favoured in the United States, puts more emphasis on the construction of the contract, allowing severance if the parties' promises can be divided into distinct obligations.

As will be shown, this author believes that when it comes to appeal clauses in arbitration agreements the inquiry should be whether the remaining agreement is still the same in its heart and whether the parties would have agreed on arbitration nevertheless. Accordingly, a combination of the "but for"-test and the test examining whether the nature of the agreement remains unaltered is regarded as the appropriate test.

This paper will begin with giving an overview of the statutory rights of appeal from arbitral awards in some developed jurisdictions. After that, it will be shown how the courts in these jurisdictions have treated agreements on rights of appeal. The major part of this paper then consists in examining the effects of clauses for rights of appeal on the remainder of the arbitration agreement.

\section{Statutory rights of appeal}

\section{A. The rule of the Model Law}

On 21 June 1985 the United Nations Commission on International Trade Law (UNCITRAL) adopted the UNCITRAL Model Law on International Commercial Arbitration1 ("the Model Law"). ${ }^{3}$ The Model Law was amended by UNCITRAL on 7 July $2006 .{ }^{4}$

\footnotetext{
${ }^{3}$ UNCITRAL Model Law on International Commercial Arbitration, United Nations Commission on International Trade Law A/40/17(SUPP), Annex I (1985).

${ }^{4}$ Revised articles of the Model Law on International Commercial Arbitration of the United Nations Commission on International Trade Law, and the recommendation regarding the interpretation of article II, paragraph 2, and article VII, paragraph 1, of the Convention on the Recognition and Enforcement of Foreign Arbitral Awards, United Nations Commission on International Trade Law A/61/17(SUPP), Annex 1 (2006).
} 
The Model Law was developed to address disparities in national laws on arbitration and further harmonization and improvement of national laws. ${ }^{5}$ It is to be used as a template when drafting a country's domestic law. ${ }^{6}$

The story of the Model Law is one of success. Legislation based on the Model Law has been enacted in close to 100 jurisdictions. $^{7}$ It can therefore be said that it is ,the single most important legislative instrument in the field of international commercial arbitration ${ }^{“ 8}$ even though most of the world's leading international arbitration centers (for instance France, England, Switzerland and the United States) have not-at least not en bloc_-adopted the Model Law. ${ }^{9}$

One of the key provisions of the Model Law is art 34, whose paragraph 1 states: "Recourse to a court against an arbitral award may be made only by an application for setting aside in accordance with paragraphs (2) and (3) of this article."

Article 34(2) of the Model Law enumerates first the grounds for setting aside an award that have to be proven by the party making the application:

- the incapacity of a party to conclude an agreement or invalidity of the agreement; ${ }^{10}$

- the lack of proper notice of the appointment of an arbitrator or the arbitral proceedings to this party or the party's inability to present its case, ${ }^{11}$

- the award deals with matters outside the scope of the submission to arbitration; ${ }^{12}$

\footnotetext{
${ }_{5}^{5}$ United Nations Commission on International Trade Law UNCITRAL 2012 digest of case law on the Model Law on International Commercial Arbitration (United Nations, New York, 2012) at 2.

${ }^{6}$ Simon Greenberg, Christopher Kee and J Romesh Weeramantry International Commercial Arbitration: An Asia-Pacific Perspective (Cambridge University Press, New York, 2011) at [150].

7 The UNCITRAL lists the states having enacted legislation based on the Model Law on $<$ www.uncitral.org/uncitral/en/uncitral_texts/arbitration/1985Model_arbitration_status.html $>$ (accessed 26 September 2014).

${ }^{8}$ Gary B Born International Commercial Arbitration (Wolters Kluwer Law \& Business, Austin, 2009) vol 1 at 115 .

${ }^{9}$ At 121; Greenberg, Kee and Weeramantry, above n 6, at [154].

${ }^{10}$ UNCITRAL Model Law on International Commercial Arbitration, United Nations Commission on International Trade Law A/40/17(SUPP), Annex I (1985), art 34(2)(a)(i).

${ }^{11}$ UNCITRAL Model Law on International Commercial Arbitration, art 34(2)(a)(ii).
} 
- the composition of the arbitral tribunal or the arbitral procedure was not in accordance with the agreement or the provisions of the Model Law. ${ }^{13}$

The grounds for setting aside an award that do not have to be proven by the party making the application, but instead should be considered by the court on its own initiative, ${ }^{14}$ are found in art 34(2)(b) of the Model Law:

- the lack of arbitrability of the subject-matter of the dispute under the law in force at the seat of arbitration; ${ }^{15}$

- a violation of the public policy at the seat of arbitration. ${ }^{16}$

It is widely accepted that these setting aside proceedings are not appeal proceedings in which the correctness of the arbitral tribunal's decision on the merits is examined. ${ }^{17} \mathrm{~A}$ large body of authority underlines that the Model Law does not permit review of the merits of an arbitral award, neither in questions of law nor in questions of fact. ${ }^{18}$

In addition, art 34 of the Model Law is perceived to be mandatory in the sense that the parties are not allowed to expand the grounds for setting aside an award. ${ }^{19}$ This interpretation is not self-evident, as it results from two of the most fundamental features of arbitration competing with each other. One of them is party autonomy: the freedom of the parties to dictate the aspects of arbitration in any manner that they choose. ${ }^{20}$ The other one is finality: the idea that an arbitrator's decision is final and binding on the parties and may be challenged only on limited grounds. ${ }^{21}$

\footnotetext{
${ }^{12}$ UNCITRAL Model Law on International Commercial Arbitration, art 34(2)(a)(iii).

${ }^{13}$ UNCITRAL Model Law on International Commercial Arbitration, art 34(2)(a)(iv).

${ }^{14}$ United Nations Commission on International Trade Law, above n 5, at 138-139.

${ }^{15}$ UNCITRAL Model Law on International Commercial Arbitration, art 34(2)(b)(i).

${ }^{16}$ UNCITRAL Model Law on International Commercial Arbitration, art 34(2)(b)(ii).

${ }^{17}$ See United Nations Commission on International Trade Law, above n 5, at 134; Greenberg, Kee and Weeramantry, above $\mathrm{n} 6$, at [930].

${ }^{18}$ See United Nations Commission on International Trade Law, above n 5, at 140, n 658-660.

${ }^{19}$ Vikram Raghavan "Heightened Judicial Review of Arbitral Awards: Perspectives from the UNCITRAL Model Law and the English Arbitration Act of 1996 on some US Developments" (1998) 15 J Int'l Arb 103 at 125-126; United Nations Commission on International Trade Law, above n 5, at 135-136.

${ }^{20}$ Mark D Wasco "When Less is More: The International Split over Expanded Judicial Review in Arbitration" (2009) 62 Rutg L Rev 599 at 599, n 1.

${ }^{21}$ At 599, n 2.
} 
Policy-makers must strike a balance between these two rivalling principles. The drafters of the Model Law have taken a stance favouring finality und thus limiting court intervention to the cases where the Model Law expressly provides for it. ${ }^{22}$ The travaux préparatoires reveal that the Commission did consider a proposal to allow parties to agree on a wider scope of court intervention in the arbitral process. ${ }^{23}$ In the end, though, concerns that parties might end up being subject to a greater degree of court intervention than they expected prevailed. ${ }^{24}$

\section{B. $\quad$ Firm statutes: United States federal law}

The United States Federal Arbitration Act can today be regarded as one of the statutes that are particularly restrictive with respect to appeals from arbitration awards.

The grounds for setting aside an arbitral award pursuant to $\S 10$ of the Federal Arbitration Act are similar to those enumerated in art 34 of the Model Law. The United States Supreme Court ruled in Hall Street Associates that $\S 10$ of the Federal Arbitration Act is to be read as exclusive. ${ }^{25}$ However, United States courts have for a long time recognized additional common law bases to set aside arbitral awards, in particular the manifest disregard doctrine. ${ }^{26}$ The United States Supreme Court's decision in Hall Street Associates thus raises the question if theses grounds can still be applied. ${ }^{27}$ In a later decision the Court expressly left unanswered the question whether the manifest disregard doctrine survived the decision in Hall Street Associates. ${ }^{28}$

\footnotetext{
${ }^{22}$ UNCITRAL Model Law on International Commercial Arbitration, United Nations Commission on International Trade Law A/40/17(SUPP), Annex I (1985), art 5.

${ }^{23}$ Report of the United Nations Commission on International Trade Law on the work of its eighteenth session (A/40/17, annex I 1985) at 62; Howard M Holtzmann and Joseph E Neuhaus $A$ guide to the UNCITRAL Model Law on International Commercial Arbitration (Kluwer Law and Taxation Publishers, Deventer (Netherlands), 1989) at 237-239 cited after Raghavan, above n 19, at 124-125.

${ }^{24}$ Report of the United Nations Commission on International Trade Law on the work of its eighteenth session, above n 23, at 64; Raghavan, above n 19, at 124-125.

${ }^{25}$ Hall Street Associates, LLC v Mattel, Inc 552 US 576 (2008) at 586.

${ }^{26}$ See Gary B Born International Commercial Arbitration (Wolters Kluwer Law \& Business, Austin, 2009) vol 2 at 2637 and 2639.

${ }^{27}$ Hall Street Associates, LLC v Mattel, Inc, above n 25, at 586 (holding "the text compels a reading of the $\S \S 10$ and 11 categories as exclusive"); Born, above n 26, at 2639.

${ }^{28}$ Stolt-Nielsen SA v AnimalFeeds International Corp (2010) 559 US 662 (2010) at 672, n 3.
} 
In any case though the manifest disregard doctrine merely adds to the grounds for recourse, whereas Hall Street Associates made it clear that the United States Federal Arbitration Act does not allow appeals from arbitration awards.

\section{Opt-in statutes}

Other jurisdictions allow the parties to an arbitration agreement to opt for a more expansive appeal from an arbitration award by the courts, while by default providing only setting aside proceedings. Examples include New Zealand and the United Kingdom.

If arbitration proceedings are governed by the law of the United Kingdom, then there is, by default, a possibility to appeal from the arbitral award with leave of the court on questions of law. ${ }^{29}$ Such leave is only granted under restrictive circumstances though. ${ }^{30}$ Leave by the court is dispensable if the parties to the arbitration have-prior to the arbitration or afterwards - agreed on an appeal to the court. ${ }^{31}$

New Zealand has essentially established the same procedure on appeals for cases of domestic arbitration in $\mathrm{cl} 5$ of sch 2 of the Arbitration Act 1996. In international arbitration however, sch 2 of the Arbitration Act 1996 is applicable only if the parties so agree. $^{32}$ If this condition is satisfied, then the parties have the possibility to appeal from arbitral awards either with leave of the court ${ }^{33}$ or as per their agreement. ${ }^{34}$

In any case though, in both jurisdictions the appeal can only be made on a question of law. ${ }^{35}$ Appeals on questions of fact are not permissible in either jurisdiction. ${ }^{36}$

\footnotetext{
${ }^{29}$ See Arbitration Act 1996 (UK), s 69(2)(b).

${ }^{30}$ David St John Sutton Russell on Arbitration (23rd ed, Sweet \& Maxwell, London, 2007) at [8-119].

${ }^{31}$ At [8-131].

${ }^{32}$ Arbitration Act 1996 s 6(2)(a).

${ }^{33}$ See Arbitration Act 1996, s 5(1)(c) of sch 2.

${ }^{34}$ Arbitration Act 1996, s 5(1)(a) and (b) of sch 2.

${ }^{35}$ See Arbitration Act 1996, s 5(1) and 5(10) of sch 2; Arbitration Act 1996 (UK), s 69(1).

${ }^{36}$ Guangzhou Dockyards Co Ltd (formerly Guangzhou CSSC-Oceanline-GSW Marine Engineering Co Ltd) $v$ Ene Aegiali I [2010] EWHC 2826, [2011] Lloyd's Rep 30 (Comm) at [17]; Carr v Gallaway Cook Allan [2014] NZSC 75 (SC) at [14].
} 


\section{Opt-out statutes}

While in the United Kingdom and New Zealand the parties may opt into a more expansive judicial review, other jurisdictions (such as Singapore and Switzerland) allow for opting out of the application of the law on international arbitration altogether and replacing it with the law on domestic arbitration.

Singapore forms part of the jurisdictions that have incorporated the Model Law in their domestic law on international arbitration. Section 3(1) of the International Arbitration Act 1994 (SG) states that, subject to this Act and with the exception of Chapter VIII on the recognition and enforcement of awards, the Model Law shall have the force of law in Singapore.

This rule applies in particular to art 34 of the Model Law $^{37}$ even though Singapore law provides two additional grounds to set aside an arbitral award: fraud or corruption in the making of the award and a breach of natural justice. ${ }^{38}$ Based on this legislation, Singapore courts have held consistently that they will not review the merits of arbitral awards: ${ }^{39}$

Errors of law or fact made in an arbitral decision, per se, are final and binding on the parties and may not be appealed against or set aside by a court except in the situations prescribed under s 24 of the Act and Art 34 of the Model Law.

Section 15(1) of the International Arbitration Act 1994 (SG) however allows the parties to an international arbitration agreement to opt out of the application of this Act and instead choose the application of the rules for domestic arbitration, which provide for appeals on questions of law. ${ }^{40}$ This opting-out must be done expressly. ${ }^{41}$

\footnotetext{
${ }^{37}$ See International Arbitration Act 1994 (SG), art 34 of sch 2.

${ }^{38}$ International Arbitration Act 1994 (SG), s 24.

${ }^{39}$ PT Asuransi Jasa Indonesia (Persero) v Dexia Bank SA [2006] SGCA 41, [2007] 1 SLR 597 (SGCA) at [57]; see also PT Perusahaan Gas Negara (Persero) TBK v CRW Joint Operation [2010] SGHC 202 (SGHC), [2010] 4 SLR 672 (SGHC) at [10]; Government of the Republic of the Philippines $v$ Philippine International Air Terminals Co, Inc [2006] SGHC 206, [2007] 1 SLR 278 (SGHC) at [38].

${ }^{40}$ See Mohan R Pillay "The Singapore Arbitration Regime and the UNCITRAL Model Law" (2004) 20 Arbitration International 355 at 366 and 375.

${ }^{41}$ David Howell, Leigh Duthie and Mark Lim "International Arbitration in Singapore: Opting out of the UNCITRAL Model Law” (2002) 19 J Int'l Arb 39 at 50.
} 
Switzerland is principally one of the more restrictive jurisdictions when it comes to appeals from arbitral awards. ${ }^{42}$ Under chapter 12 of the Bundesgesetz über das Internationale Privatrecht 1987 (Federal Act on the Private International Law (PILA)), only setting aside proceedings are available, and the grounds to set aside an award are procedural (with the exception of the ground of violation of the ordre public). ${ }^{43}$

As per art 176(2) of the PILA however, the parties may agree to opt out of the application of chapter 12 of the PILA and instead have their arbitration governed by part 3 of the Schweizerische Zivilprozessordnung ${ }^{44}$. Pursuant to art 393 of the CPC, an arbitral award may be set aside by a court if its outcome is arbitrary because the award "is based on findings that are obviously contrary to the facts as stated in the case files or because it constitutes an obvious violation of law or equity". ${ }^{45}$

While these setting aside proceedings encompass questions of fact, the standard that needs to be met is considerably higher compared to appeals from court decisions where it is enough for the appellant to show that the decision is merely wrong, either factually or legally: An appeal may be filed on grounds of incorrect application of the law or incorrect establishment of the facts. ${ }^{46}$

\section{Treatment of agreements on (expanded) rights of appeal}

In several jurisdictions some parties to an arbitration agreement have tried to incorporate rights of appeal to a court into their agreement. It is not easy to see why parties should do so, as such an agreement potentially erases most of the advantages that come with

\footnotetext{
${ }^{42}$ See Jean-François Poudret and Sébastien Besson Comparative Law of International Arbitration (2nd ed, Sweet \& Maxwell, London, 2007) at [786].

${ }^{43}$ Bundesgesetz über das Internationale Privatrecht 1987, art 190(2) (translation: Federal Act on the Private International Law); Poudret and Besson, above n 42, at [821], [824]-[827].

${ }^{44}$ Translation: Civil Procedure Code (CPC). The CPC replaced the Intercantonal Convention on Arbitration of 1969 (known as the "Concordat") in 2011.

${ }^{45}$ Schweizerische Zivilprozessordnung 2011, art 393(e) (translation: Civil Procedure Code) as per the semiofficial translation on <www.admin.ch/opc/en/classified-compilation/20061121/index.html> (accessed 26 September 2014).

${ }^{46}$ Schweizerische Zivilprozessordnung 2011, art 310 (translation: Civil Procedure Code).
} 
arbitration (confidentiality, speed). Nevertheless, such cases have occurred, and courts have been forced to assess those agreements. ${ }^{47}$

\section{A. Invalidity of such agreements}

Agreements on rights of appeal are not precluded by international conventions, in particular not by the New York Convention ${ }^{48}{ }^{49}$ Whether such agreements are given effect to is thus a matter of national law. ${ }^{50}$

While some federal courts in the United States used to uphold agreements on rights of appeal, ${ }^{51}$ the overwhelming majority of the courts took a different view: The Supreme Courts of both New Zealand ${ }^{52}$ and the United States ${ }^{53}$ as well as courts in France ${ }^{54}$ declined to give effect to such agreements. Similarly, the High Court of England and Wales held it to be "very doubtful" that the parties could agree for an appeal on questions of fact. ${ }^{55}$

No pertinent decisions of Swiss or Singaporean courts are known to this author. But it is presumed that the courts of both Singapore and Switzerland would hold such agreements to be invalid as they aim to amend the provisions on the setting aside of arbitration awards which are deemed as mandatory. ${ }^{56}$ In Switzerland this can be derived e

\footnotetext{
$\overline{{ }^{47} \text { See eg Kyocera Corp v Prudential-Bache Trade Services, Inc 341 F 3d } 987 \text { (9th Cir } 2003 \text { en banc); Carr }}$ $v$ Gallaway Cook Allan, above n 36.

${ }^{48}$ United Nations Convention on the Recognition and Enforcement of Foreign Arbitral Awards, 330 UNTS 3 (opened for signature 10 June 1958, entered into force 7 June 1959).

${ }^{49}$ See Albert Jan van den Berg The New York Arbitration Convention of 1958: Towards a Uniform Judicial Interpretation (Kluwer Law and Taxation, Deventer (Netherlands), 1981) at 157-158.

${ }^{50}$ At 158.

${ }^{51}$ See Born, above $\mathrm{n} 26$, at 2668.

${ }^{52}$ See Carr v Gallaway Cook Allan, above n 36, at [14].

${ }^{53}$ See Hall Street Associates, LLC v Mattel, Inc, above n 25.

${ }^{54}$ See Emmanuel Gaillard and John Savage Fouchard, Gaillard, Goldman On International Commercial Arbitration (Kluwer Law International, The Hague, 1999) at [1596] n 159.

${ }^{55}$ See Guangzhou Dockyards Co Ltd (formerly Guangzhou CSSC-Oceanline-GSW Marine Engineering Co Ltd) $v$ Ene Aegiali I, above n 36, at [30].

${ }^{56}$ See Poudret and Besson, above $\mathrm{n} 42$, at [788] (holding that the list of the grounds for invalidity provided for in the laws examined is exhaustive and adding in footnote 115, referring to the Kyocera decision: "We doubt that this interpretation which is very respectful of the intent of the parties is compatible with the laws considered in this book.").
} 
contrario from art 192 of the PILA: While this provision states that non-Swiss resident parties may exclude any recourse to the courts or particular grounds for recourse,${ }^{57}$ there is no corresponding provision for expanding the grounds for recourse.

A judgment of the German Bundesgerichtshof ${ }^{58}$ of $2007^{59}$ is sometimes interpreted as giving effect to expanded judicial review clauses. ${ }^{60}$ This is, however, incorrect as the Court merely enforced a clause stating that any party not satisfied with the arbitral award could file suit with a competent court within a month after the award had been rendered. ${ }^{61}$ It is true that the Court held that arbitration is based on the principle of contractual freedom and that the parties are accordingly free to attach certain conditions to their being bound to the award. ${ }^{62}$ A conditional submission of the parties to the arbitral award was therefore permissible. ${ }^{63}$

However, it is submitted that the crucial point is that such an agreement interferes in no way with the procedure provided by the law. The same cannot be said of appeal agreements, where the parties seek to amend an appellate court's jurisdiction. Against this background, it should not easily be assumed that the Bundesgerichtshof would allow an appeal agreement. While there is no pertinent German judgment available yet, ${ }^{64}$ German legal scholars are in the majority of the opinion that the parties may not by agreement expand the judicial review of arbitral awards. ${ }^{65}$

\footnotetext{
57 Bundesgesetz über das Internationale Privatrecht 1987 (translation: Federal Act on the Private International Law) (Switzerland), art 192(1).

58 Translation: Federal Court of Justice. This is the highest appellate court in Germany for civil and criminal cases.

${ }^{59}$ Undisclosed v undisclosed [2007] 25 ASA Bulletin 810, [2008] 33 Yearbook Comm Arb'n 231 (BGH).

${ }^{60}$ See Neida Cunaj "Separability within the arbitration clause with special focus on US jurisdictions" (LLM short thesis, Central European University, 2014) at 34 n 156.

${ }^{61}$ Undisclosed $v$ undisclosed, above n 59, at 235; see also Matthias Scherer "Introduction to the Case Law Section" (2007) 25 ASA Bulletin 750 at 753-754.

${ }^{62}$ Undisclosed $v$ undisclosed, above n 59, at 235.

${ }^{63}$ At 236.

${ }^{64}$ But see Undisclosed v undisclosed [2006] SchiedsVZ 103 (OLG Naumburg) at 104 (holding obiter that the parties cannot expand the grounds for setting aside by agreement).

${ }^{65}$ See eg Stefan Kröll and Peter Kraft “§ 1059 - Application for Setting Aside” in Karl-Heinz Böckstiegel, Stefan Kröll and Patricia Nacimiento (eds) Arbitration in Germany: the Model Law in Practice (Kluwer Law International, Alphen aan den Rijn (The Netherlands), 2007) at [37]; but see Gerhard Wagner " $\$ 1026$

- Extent of Court Intervention” in Karl-Heinz Böckstiegel, Stefan Kröll and Patricia Nacimiento (eds)
} 


\section{B. Separability of such agreements}

Given the courts' view of the clauses on rights of appeal as invalid the question arises whether the invalidity of said clause renders the entire arbitration agreement invalid. In order to prevent consequences of this kind-albeit in different constellations-, the doctrine of separability (or autonomy) has been developed.

The doctrine of separability is a theory well established in jurisdictions all over the world. The doctrine states that an arbitration clause contained in a contract is an agreement separate from the main contract of which it forms part. ${ }^{66}$ Thus, it survives the main contract's termination and may be valid despite the main contract's invalidity. ${ }^{67}$

The Model Law has codified the doctrine of separability in art 16(1):

The arbitral tribunal may rule on its own jurisdiction, including any objections with respect to the existence or validity of the arbitration agreement. For that purpose, an arbitration clause which forms part of a contract shall be treated as an agreement independent of the other terms of the contract. A decision by the arbitral tribunal that the contract is null and void shall not entail ipso jure the invalidity of the arbitration clause.

The doctrine of separability is today accepted in all developed arbitral jurisdictions, including the jurisdictions that have adopted the Model Law. ${ }^{68}$ Namely, both New Zealand and Singapore have adopted art 16(1) of the Model Law. ${ }^{69}$

The question therefore arises whether an agreement on rights of appeal from an arbitral award is independent of the (basic) agreement to arbitrate. The answer is not selfevident. An argument can be made - and indeed was made in Carr $v$ Gallaway Cook

\footnotetext{
Arbitration in Germany: the Model Law in Practice (Kluwer Law International, Alphen aan den Rijn (The Netherlands), 2007) at [8] (arguing agreements on an expansions of judicial review should be honoured).

${ }^{66}$ Born, above n 8, at 311; Gaillard and Savage, above n 54, at [389]; Blackaby and others, above n 1, at [2.89]; Greenberg, Kee and Weeramantry, above $\mathrm{n} 6$, at [436].

${ }^{67}$ Blackaby and others, above $\mathrm{n} 1$, at [2.89]; Born, above $\mathrm{n} 8$, at 357.

${ }^{68}$ Blackaby and others, above n 1, at [2.96] and [2.98]; Greenberg, Kee and Weeramantry, above n 6, at [439]; R Doak Bishop, Wade M Coriell and Marcelo Medina Campos "The 'Null and Void' Provision of the New York Convention" in Emmanuel Gaillard and Domenico Di Pietro (eds) Enforcement of Arbitration Agreements and International Arbitral Awards: The New York Convention in Practice (Cameron May, London, 2008) 275 at 279.

${ }^{69}$ See Arbitration Act 1996 s 16(1) of sch 1; International Arbitration Act 1994 (SG) art 16(1) of sch 1.
} 
$\operatorname{Allan}^{70}$ - that the arbitration process, which is the subject matter of the arbitration agreement, ends with the award being rendered. Court proceedings that are initiated after the award has been made on the other hand are governed by a different regime and, consequently, by a different agreement. ${ }^{71}$

The underlying question is therefore whether the doctrine of separability applies to save the arbitration agreement only from deficiencies of the main contract or also from deficiencies in ancillary provisions of the arbitration agreement itself.

Traditionally, the doctrine of separability has been understood to apply in the former cases only. ${ }^{72}$ The Supreme Court of New Zealand maintained this view in Carr. It first noted that the doctrine of separability prevented from the consequence that, "if an arbitrator held that there was a defect in the contract that rendered it invalid, this would be to determine that the arbitration clause itself was invalid". ${ }^{73}$ The Court then went on to hold that there was no possibility of such a result "where an arbitration clause is contained in a submission agreement that is distinct and separate from the contract to which the dispute being submitted to arbitration relates."74 Thus, the Court concluded, the meaning of "arbitration agreement" as per art 16 of the Arbitration Act 1996, which codifies the doctrine of separability, is not to be confined so as to exclude the procedural terms agreed by the parties. $^{75}$

And this is in this author's opinion the correct interpretation. While it is true that appeal agreements deal with proceedings that are different from the arbitration proceedings, they are still very closely connected with the underlying arbitration agreement as they aim to regulate the finality of the arbitral award. There is a substantial

\footnotetext{
${ }^{70}$ See Carr v Gallaway Cook Allan, above n 36, at [35].

${ }^{71}$ See Kyocera Corp v Prudential-Bache Trade Services, Inc, above n 47, at 1000; Tibor Varady "On the Option of a Contractual Extension of Judicial Review of Arbitral Awards - Or: What is Actually ProArbitration?" (2006) 56 Zbornik PFZ 455 at 472-473.

${ }^{72}$ See Gaillard and Savage, above n 54, at [389 and 410]; but see Umar A Oseni and Hunud Abia Kadouf "The Discrimination Conundrum in the Appointment of Arbitrators in International Arbitration" (2012) 29 J Int'l Arb 519 at 542 (arguing the rule of separability may also be applied to an arbitration clause and to any controversial clause within it).

${ }^{73}$ Carr v Gallaway Cook Allan, above n 36, at [43].

${ }^{74}$ At [44].

${ }^{75}$ At [44].
} 
link between provisions relating to the arbitration process (or the finality of the arbitral award) and the arbitration agreement and that link should not be disregarded. It can hardly be said that they are more connected with the main contract than with the arbitration agreement. In addition, as the Supreme Court observed, the rationale for the separation of the arbitration agreement from the main contract (the tribunal's ability to declare the main contract invalid without contradicting its jurisdiction) does not extend to situations where provisions relating to the arbitration process are at stake. ${ }^{76}$

However, note should be taken of a recent decision of the United States Supreme Court on whether the arbitrator or a court is competent to rule on the validity of the arbitration agreement. ${ }^{77}$ The Court separated a provision within an arbitration agreement that gave the arbitrator "exclusive authority to resolve any dispute relating to the enforceability of this Agreement" 78 from the remaining arbitration agreement. It held that the application of the rule "does not depend on the substance of the remainder of the contract". ${ }^{79}$ A minority of the Court dissented on the application of the separability doctrine, holding: "[T] hat the subject matter of the agreement is exclusively arbitration makes all the difference", ${ }^{80}$

\section{Severability of such agreements}

Since the doctrine of separability does not apply to appeal clauses, the question remains whether an appeal clause invalidates the entire arbitration agreement.

In common law jurisdictions this is a matter to be resolved according to the doctrine of severance; in Switzerland and other civil law countries the doctrine of partial nullity applies.

\footnotetext{
${ }^{76}$ At [43] and 44].

${ }^{77}$ Rent-A-Center, West, Inc v Jackson 561 US 63 (2010).

${ }^{78}$ At 71.

${ }^{79}$ At $71-72$.

${ }^{80}$ At 77 per Stevens, Ginsburg, Breyer and Sotomayor dissenting.
} 
On a few occasions courts simply assumed without examining the issue that the arbitration agreement was valid despite the offending clause. ${ }^{81}$ Where however the validity of the arbitration agreement was in dispute, the courts of the various jurisdictions applied different tests to determine if the arbitration agreement could be upheld.

Three fundamentally different approaches can be found in the jurisdictions examined in this paper. Switzerland and some jurisdictions in the United States follow an approach that inquires into the actual or hypothetical subjective intentions of the parties: Would the parties have entered into the agreement without the clause to be severed?

A second approach looks at the contract that the parties have agreed on and tries to preserve its character, thus asking: Will the agreement still be substantially the same without the clause to be severed ${ }^{82}$

A third approach puts more emphasis on the construction of the contract, examining if the parties' performances can be divided and apportioned into corresponding pairs of part performances. The question then becomes: Does the agreement still provide pairs of promises of roughly equivalent value without the clause to be severed ${ }^{83}$

\section{Doctrines of severance and partial nullity}

\section{A. The "but for"-test}

The probably most straightforward way ${ }^{84}$ to resolve the issue is to apply a "but for"-test, asking whether the parties would have entered into the agreement but for the illegal parts.

\footnotetext{
${ }^{81}$ See eg Bowen v Amoco Pipeline Co 254 F 3d 925 (10th Cir 2001) at 937; Saika v Gold 56 Cal Rptr $2 \mathrm{~d}$ 922 (Cal App 1996).

82 Sir Jack Beatson, Andrew Burrows and John Cartwright Anson's law of contract (29th ed, Oxford University Press, Oxford, 2010) at 433.

${ }^{83}$ See E Allan Farnsworth Farnsworth on contracts (3rd ed, Aspen Publishers, New York, 2004) at 382.

${ }^{84}$ Notably, various legal scholars have assumed (without in-depth examination) that courts would apply a "but for"-test: see Raghavan, above n 19, at 123; Margaret Moses "Can Parties Tell Courts What to Do? Expanded Judicial Review of Arbitral Awards” (2004) 52 U Kan L Rev 429 at 462.
} 
However, the outcome will not necessarily be the same wherever the "but for"-test is applied, as it is dependent on the point of reference for the test: the very parties with all their flaws and eccentricities or the parties as reasonable persons acting in good faith?

\section{The "but for"-test in the United States}

\section{a) The pure "but for"-test}

The "but for"-test in its pure form is in the United States applied by Texan courts. ${ }^{85}$ Under Texas law, the test of severability consists of two parts. The first is to determine if the illegal promise is the original consideration of the contract or merely incidental. ${ }^{86}$ Severance is only possible in the latter case. The second part is the "but for"-test: "The issue as to severability is whether or not the parties would have entered into the agreement absent the illegal parts". 87

The case of Whiteside $v$ Griffis \& Griffis, PC involved a dispute between a lawyer and the law firm where he previously used to work. He was promised a goodwill payment for not competing with the law firm within a radius of 300 miles. This promise was held to be in violation of Texas law. ${ }^{88}$ The findings of fact revealed that the law firm would not have agreed to pay a goodwill factor, had they known that the promise not to compete was void and unenforceable. ${ }^{89}$ It was also established that it would have been economically impossible for the law firm to make a goodwill payment to all departing shareholders. ${ }^{90}$

The dispute in Rogers $v$ Wolfson ${ }^{91}$ was between the sellers of one-half interest in a partnership (Rogers) and the buyer (Wolfson). The district court had, in a summary judgment, declined Rogers' suit for money due under the sales contract because it found

\footnotetext{
${ }_{85}$ Jeremy L Zell "Discerning the Validity of Arbitration Agreements Containing Heightened Judicial Review Clauses after Hall Street Associations, LLC v Mattel, Inc” 40 Loy U Chi LJ 959 at 969.

${ }^{86}$ Rogers $v$ Wolfson 763 SW 2d 922 (Tex Ct App 1989) at 925; Whiteside v Griffis \& Griffis, PC 902 SW 2d 739 (Tex App-Austin 1995) at 744.

${ }^{87}$ McFarland v Haby 589 SW 2d 521 (Tex Civ App 1979) at 524; Rogers v Wolfson, above n 86, at 925.

${ }^{88}$ Whiteside $v$ Griffis \& Griffis, PC, above n 86, at 743-744.

${ }^{89}$ At 745.

${ }^{90}$ At 745 .

${ }^{91}$ Rogers $v$ Wolfson, above n 86.
} 
some ancillary provisions of the sales contract to be illegal under Texas antitrust laws. ${ }^{92}$ Upon appeal, the Court of Appeal held in favour of Rogers. Given that the illegal provisions were solely to the benefit of Rogers who had first indicated their illegality and then nevertheless consummated the sale, the Court of Appeal found that the parties would have entered into the agreement without the illegal provisions. ${ }^{93}$

The crucial point in time to determine the parties' intent is the time of the execution of the agreement. ${ }^{94}$ The point of reference seems to be the intention of the parties as they then were: The Courts will in principle rely on factual evidence on the parties' subjective intent, ${ }^{95}$ although they tend to validate the factual findings by considering which course of action they deem reasonable. ${ }^{96}$

\section{b) The modified "but for"-test: Oklahoma and Alaska}

Oklahoma and Alaska courts apply what could be called a modified version of the "but for"-test: The goal of the analysis is to determine whether the illegal part is an essential part of the agreed exchange, the rationale being that then the parties would not have entered into the agreement at all without it. The Supreme Court of Alaska explained this in Zerbetz: ${ }^{97}$

If a provision that the court must excise is an "essential part of the agreed exchange," the court cannot be sure that in that provision's absence the parties would have agreed at all. In that case the court should not enforce what remains of the agreement.

The Supreme Court of Oklahoma followed Zerbetz in Hargrave: ${ }^{98}$

The enforceability of the remaining portions is dependent upon the expectations of the parties. If the invalid contractual provision is an essential part of the agreement 
and the parties would not have agreed absent that provision, then the entire contract is unenforceable.

When examining an arbitration agreement that contained an illegal attorney fee provision, the District Court of Northern Oklahoma held, applying Hargrave: ${ }^{99}$

The primary purpose of this arbitration agreement is to provide a mechanism to resolve employment related disputes. The court finds the attorney fee provision is not an "essential part" of the contract and, given the "liberal federal policy favoring arbitration agreements," concludes severance of the offending provision is appropriate.

It does not appear that the Court examined whether the parties would have concluded the arbitration agreement absent the illegal provision. Rather, the court determined if the illegal clause was an essential part according to an objective standard. This can be seen as a shortcut as it allows the courts to apply their own judgement as an objective standard instead of having to rely on evidence of the parties' subjective intentions.

\section{The "but for"-test in Switzerland}

The "but for"-test is what Swiss legislation prescribes in the Code of Obligations. The pertinent provision is art 20 of the Code of Obligations: ${ }^{100}$

(1) A contract is void if its terms are impossible, unlawful or immoral.

(2) However, where the defect pertains only to certain terms of a contract, those terms alone are void unless there is cause to assume that the contract would not have been concluded without them.

The question whether the contract would have been concluded without the void terms is to be answered by ascertaining the putative or hypothetical intent of the parties, unless their actual intent can be proven. ${ }^{101}$ The hypothetical intent of the parties is to be determined by examining what the parties would have agreed on, had they known about the invalidity of the provision. ${ }^{102}$ The relevant point in time is the time of conclusion of

\footnotetext{
${ }^{99}$ Munoz v Green Country Imports, LLC Distr Ct, ND Okl 12-CV-322-GKF-FHM, 3 October 2012 at 5.

100 Obligationenrecht 1911 (translation: Code of Obligations) (Switzerland), art 20 as per the semi-official translation on <www.admin.ch/opc/en/classified-compilation/19110009/index.html> (accessed 26 September 2014).

${ }^{101} X v A A G[2005] 131$ III BGE/ATF 467 at 470.

${ }^{102} X v A$ BGer 4C.156/2006, 17 August 2006 at consid 3.3.
} 
the agreement. ${ }^{103}$ The Federal Supreme Court of Switzerland, the Bundesgericht ${ }^{104}$ noted that there is a split of authorities as to the point of reference: Some legal scholars argue the court should ask what reasonable parties acting in good faith would have agreed on. Other scholars think the court should ask what the specific parties to the dispute would have agreed on; only if this cannot be established should the court rely on the objective intentions of the parties acting in good faith. ${ }^{105}$ The Bundesgericht suggested that the two opinions might be reconciled if the inquiry into the objective intentions of reasonable parties was based on the parties to the dispute rather than some reasonable model parties and if all the circumstances relating to the contract are taken into account. ${ }^{106}$ Indeed, this seems to have been the preferred approach in a number of older judgments, where it was held that the court should consider the contract in its entirety and its goals as well as all the circumstances. ${ }^{107}$

When in doubt, partial voidness is to be preferred over full voidness of the contract according to the principle of in favorem validatis. ${ }^{108}$ Therefore, the burden of proof lies with the party arguing full voidness of the agreement. ${ }^{109}$ If however no hypothetical agreement of the parties may be ascertained then the whole contract is void. ${ }^{110}$

In a recent decision the Bundesgericht applied the rules of art 20 of the Code of Obligations to an arbitration agreement in a dispute between an agent company and a football club. ${ }^{111}$ The agreement appointed alternatively two commissions of the FIFA ${ }^{112}$ and the UEFA ${ }^{113}$ as the competent instance to decide the case. However, both commissions did not have jurisdiction on disputes such as the case at hand. The Court therefore held that this part of the agreement was impossible pursuant to art 20(1) of the

$\overline{{ }^{103} Y v X \text { [1984] } 110 \text { Ia BGE/ATF } 59 \text { at 63; } A v B S A \text { [1997] } 124 \text { III BGE/ATF } 57 \text { at 60; } X v A \text {, above } \mathrm{n} 102}$ at consid 3.1.

104 Translation: Swiss Federal Court.

${ }^{105} X v A$, above $\mathrm{n} 102$ at consid 3.3.

${ }^{106} X v A$, above $\mathrm{n} 102$ at consid 3.3.

${ }^{107}$ See eg $Y v X$, above $\mathrm{n} 103$, at 63 .

${ }^{108} X v A$, above $\mathrm{n} 102$ at consid 3.2; Football club Xv Y Sàrl [2011] 138 III BGE/ATF 29 at 39.

${ }^{109} X v A$, above $\mathrm{n} 102$ at consid 3.2.

${ }^{110} X v A$, above $\mathrm{n} 102$ at consid 3.4.

${ }^{111}$ Football club Xv Y Sàrl, above n 108.

${ }^{112}$ Fédération Internationale de Football Association.

${ }^{113}$ Union of European Football Associations. 
Code of Obligations and consequently invalid. ${ }^{114}$ The question was thus whether the parties would have chosen to agree on arbitration, had they known about the invalidity of the appointment. The circumstances of the case, in particular the fact that two alternative commissions had been appointed, made it clear that the parties were not fixated on one specific institution. ${ }^{115}$ Therefore, the Court found that the parties would still have opted for arbitration and upheld the remainder of the arbitration agreement. ${ }^{116}$ It found that the parties hypothetically would have agreed on an arbitral tribunal specialised on sports matters, i.e. the CAS/TAS, which had eventually admitted jurisdiction. ${ }^{117}$ The Court backed up its reasoning by noting that the CAS/TAS would have been competent to review the decision of the FIFA commission on appeal if the latter had accepted jurisdiction. ${ }^{118}$

In an interesting line of argument, the appellant submitted that it was deprived of its rights of appeal to the CAS/TAS due to the CAS/TAS admitting direct jurisdiction. The Court rejected this argument by noting that this issue followed directly from the lack of jurisdiction of the FIFA commission. It added that the appellant had failed to show how the parties would have insisted on the possibility of appeals at any rate. ${ }^{119}$

The degree of leniency shown in this case by the Bundesgericht towards arbitral tribunals that have admitted jurisdiction based on imperfect arbitration agreements is not unparalleled. ${ }^{120}$ The Bundesgericht had previously admitted the validity of an arbitration agreement that provided an impossible procedure to appoint the tribunal. ${ }^{121}$

Swiss case law thus suggests that a party wishing to invalidate an arbitration agreement based on an invalid appeal clause must be able to furnish substantive evidence that it would not have agreed to arbitrate in the first place without rights of appeal.

\footnotetext{
${ }^{114}$ Football club Xv Y Sàrl, above n 108, at 37-38.

115 At 38.

116 At 39.

117 At 38-39.

118 At $39-40$.

119 At 40 .

120 See generally Luca Beffa "Decision 4A_246/2011 or the Leniency of the Swiss Federal Tribunal Towards Pathological Clauses" (2012) 30 ASA Bull 169 at 174-176.

${ }^{121} A A G v B N V$ [2003] 130 III BGE/ATF 66 at 73-74.
} 


\section{The "but for"-test in Continental Europe}

The "but for"-test is the prevailing standard not only in Switzerland, but also in continental Europe, in particular in Germany ${ }^{122}$ and France. ${ }^{123}$ In France, the Paris Cour d'appel held in the case of Société de Diseno v. Société Mendes an appeal agreement to be null and void. ${ }^{124}$ Regarding the question whether the arbitration agreement may survive the nullity of the appeal provision, the Court found that said provision constituted an element of the arbitration agreement that was essential and decisive for the consent of the parties, which had affirmed in this way their wish to submit their dispute to two levels of jurisdiction: ${ }^{125}$

Considérant que cette clause est en conséquence frappée d'une nullité qui affecte dans son ensemble la convention d'arbitrage dont elle constitue un élément essentiel, déterminant du consentement des parties qui ont ainsi affirmé leur volonté de soumettre leur litige à deux degrés de juridiction; ...

Accordingly, the whole arbitration clause was invalid. While the wording seems to indicate that the Court relied on the provision being both an essential element and a decisive factor for the parties' consent, French legal scholars perceive the Court's reasoning as a "but for"-test. ${ }^{126}$

\section{Appraisal of the "but for"-test}

\section{a) Rejection of the "but for"-test in the Commonwealth}

The "but for"-test has not been accepted in the Commonwealth jurisdictions.

In the case of Alec Lobb (Garage) Ltd v Total Oil (Great Britain) Ltd, the defendant, Total, had granted a leaseback of property subject to tie provisions to supply all the petrol

\footnotetext{
$122 \S 139$ of the Buergerliches Gesetzbuch (BGB) provides: „Ist ein Teil eines Rechtsgeschäfts nichtig, so ist das ganze Rechtsgeschäft nichtig, wenn nicht anzunehmen ist, dass es auch ohne den nichtigen Teil vorgenommen sein würde." (translation: "If a part of a legal transaction is void, then the entire legal transaction is void, if it cannot be assumed that it would have been undertaken even without the void part.")

${ }^{123}$ See Norman S Marsh "The Severance of Illegality in Contract" 64 LQR 230 at 230.

${ }^{124}$ Société de Diseno v Société Mendes [1995] Revue de l'Arbitrage 263 (Cour d'Appel de Paris) at 266 quoted after Varady, above n 71, at 467 n 37.

${ }^{125}$ Société de Diseno v Société Mendes, above n 124, at 267 quoted after Varady, above n 71, at 468 n 38.

${ }^{126}$ See Gaillard and Savage, above n 54, at [1597]; Laurence Franc "Contractual Modification of Judicial Review of Arbitral Awards: The French Position” (1999) 10 Am Rev Int'l Arb 215 at 222; but see Varady, above $\mathrm{n} 71$, at $467-468$.
} 
for the business. The Court of Appeal of England and Wales held that the tie provisions, if invalid, were severable from the valid and enforceable parts of the lease and leaseback: ${ }^{127}$

The contract is of course changed by the excision of the tie, and obviously Total would not have granted a lease-back which did not contain such a tie. But I do not think that is good enough to prevent severance and lead to the conclusion that the whole of the lease and lease-back is void.

In Marshall, the same court held: ${ }^{128}$

But it is often and perhaps usually the case that the promise would not have been given but for the invalid restraint, yet this does not prevent the contract from being enforced without the invalid provision...

Along the same lines, the Singapore High Court held, quoting from Restrictive Covenants under Common and Competitive Law, ${ }^{129}$ that "even if the covenantee would not have entered the agreement without the covenant, the contract may not be invalidated as a whole if there is consideration independent of the covenant". ${ }^{130}$

In the Australian case of Carney $v$ Herbert, the defendant suggested using a "but for"test, arguing that the counterparty would have declined to enter into the contract without the void provision. ${ }^{131}$ The Privy Council did not "accept the relevance of any such inquiry" and thus rejected the argument. ${ }^{132}$

Most recently, the Supreme Court of New Zealand contemplated in Carr the appropriate test of severability with regard to appeal agreements. While it did not explicitly reject the "but for"-test, it did emphasise that the approach it applied in the judgment was not a subjective inquiry into the parties' intentions. ${ }^{133}$

127 Alec Lobb (Garages) Ltd $v$ Total Oil (Great Britain) Ltd [1985] 1 WLR 173 (CA) at 181.

${ }^{128}$ See Marshall v NM Financial Management Ltd [1997] 1 WLR 1527 (UKCA) at 1532.

${ }^{129}$ Alexandra Kamerling and Christopher Osman Restrictive Covenants under Common and Competition Law (5th ed, Sweet \& Maxwell, London, 2007) at 45.

${ }^{130}$ Wong Bark Chuan David v Man Financial (S) Pte Ltd [2007] SGHC 5, 2 SLR 22 (SGHC) at [213].

${ }^{131}$ Carney v Herbert [1985] AC 301 (PC) at 316.

${ }^{132}$ At 316.

${ }^{133}$ Carr v Gallaway Cook Allan, above n 36, at [66]. 
To summarise, the courts of the Commonwealth have always, when dealing with the issue of severability, applied tests that were based on an objective analysis of the agreement rather than on an inquiry into the subjective intentions of the parties.

\section{b) Grounds for rejection of the "but for"-test}

Why do the courts of the Commonwealth reject the "but for"-test?

In Alec Lobb the defendant, Total, had granted the plaintiffs a leaseback of property subject to tie provisions to supply all the petrol for the business of the plaintiffs. ${ }^{134}$. The Court found, however, the purportedly invalid provision to be a reasonable and therefore valid restraint of trade clause. ${ }^{135}$ In an obiter dictum the Court observed that Total, if it had imposed an invalid restraint of trade, could not have argued that it would not have entered into the contract absent the illegal tie ${ }^{136}$.

In Marshall the plaintiff, who had been engaged as a self-employed sales agent by the defendant, had been promised a post-termination commission. The promise was purportedly given in exchange for a promise not to compete with the defendant, which was found to be an unreasonable restraint of trade. ${ }^{137}$ The defendant tried to avoid its promise being enforced by arguing that it would not have given the promise without the invalid restraint of trade. ${ }^{138}$ The Court held that this did not prevent severance. ${ }^{139}$ The Court then found that the payments to the sales agent were in substance not consideration for the promise not to compete but for the sales agent's previous services. ${ }^{140}$

Marshall and Alec Lobb have in common that they both dealt with an actually or allegedly unreasonably wide promise, which had been imposed by and was to the sole benefit of the counterparty. There were therefore certainly good reasons not to give effect to the counterparty's argument that they would not have entered into the agreement absent the invalid clause. However, the two cases are hardly comparable to the case of

\footnotetext{
${ }^{134}$ Alec Lobb (Garages) Ltd v Total Oil (Great Britain) Ltd, above n 127, at 173.

135 At 180 and 191.

${ }^{136}$ At 181 and 192.

${ }^{137}$ Marshall v NM Financial Management Ltd, above n 128, at 1528.

${ }^{138}$ At 1531 .

${ }^{139}$ At 1532.

${ }^{140}$ At 1534 .
} 
appeal agreements: An appeal clause is, as a matter of principle, neutral, i.e. of equal value to both parties and therefore not to the benefit of one party. ${ }^{141}$ Of course, it is very much to the benefit of the party that lost in the arbitral proceedings, but this is not due to its construction but to the outcome of the arbitration. ${ }^{142}$

For the same reason the rationale of Carney does not apply either: The Carney court was concerned with an agreement for the sale of shares in a company, and in particular with an illegal mortgage, which had been promised as a security for the purchase price by Carney, the buyer of the shares. ${ }^{143}$ When the mortgage was found to be illegal and void, Carney, who had not yet paid the full purchase price, argued that the counterparty would not have agreed to the sale absent the mortgage provision. ${ }^{144}$ The Privy Council, having noted that the sellers were ready to proceed without the mortgage, rejected this argument and went on to hold: ${ }^{145}$

Subject to a caveat that it is undesirable, if not impossible, to lay down any principles which will cover all problems in this field, their Lordships venture to suggest that, as a general rule, where parties enter into a lawful contract of, for example, sale and purchase, and there is an ancillary provision which is illegal but exists for the exclusive benefit of the plaintiff, the court may and probably will, if the justice of the case so requires, and there is no public policy objection, permit the plaintiff if he so wishes to enforce the contract without the illegal provision.

As an appeal clause is not to the sole benefit of one party, the general rule formulated in Carney, under which a "but for"-test must be rejected, does not apply to appeal agreements.

Applying a "but for"-test means that literally each case will turn on its facts. The construction of the agreement becomes less important than the motivation of the parties to opt for arbitration in the first place. If, for instance, it can be shown that one party insisted on including an appeal clause, then the courts will find it difficult to uphold the arbitration agreement against that party's will. Should however the clause be part of a

\footnotetext{
${ }^{141}$ But see, for an exception, Beynon v Garden Grove Medical Group (1980) 100 Cal App 3d 698, at 704, n 2, 161 Cal Rptr 146, at 149, n 2.

142 Carr v Gallaway Cook Allan [2012] NZHC 1537, [2012] 3 NZLR 97 (HC) at [42].

${ }^{143}$ Carney v Herbert, above n 131, at 301.

144 At 316.

145 At 317.
} 
boilerplate arbitration agreement, which the parties inserted into a contract without deliberating on it, then the courts will be more inclined to enforce the arbitration agreement.

While the parties' negotiations gain thus considerable weight, the key is - as long as a pure "but for"-test is applied - the subjective intention of one party, which did not even need to be indicated to the counterparty.

Courts and legal scholars aim to counter-balance the danger of relying on a party's purely subjective intentions by applying modified, more objective standards. In this author's view, this is not wholly persuasive nor is it consistent with the idea of a "but for"-test. While the motivation is understandable, this author suggests that a preferable approach would be to combine the "but for"-test as a (purely) subjective inquiry with the test of severance applied in the Commonwealth as an objective inquiry. ${ }^{146}$

\section{B. The test examining the effect on the nature of the promises}

\section{The test in the Commonwealth}

In the past, legal scholars in the Commonwealth put forward, and the courts of the Commonwealth applied, differing criteria to examine whether a part of a contract may be severed. ${ }^{147}$ Requirements that in the recent past needed to be met before severance was permitted are as follows:

a) The promise to be severed must be of such a kind that can be severed (thus excluding criminal or immoral promises). ${ }^{148}$

b) The court must not be forced to redraft the contract ("blue pencil" test). ${ }^{149}$

\footnotetext{
146 See below IV.B.4.

147 Amoco Australia Pty Ltd v Rocca Bros Motor Engineering Co Pty Ltd [1975] AC 561 (PC) at 578; Beatson, Burrows and Cartwright, above n 82, at 433.

148 Bennett v Bennett [1952] 1 KB 249 (CA) at 253/254; Goodinson v Goodinson [1954] 2 QB 118 (CA) at 120; Carney v Herbert, above n 131, at 311; Edwin Peel The Law of Contract (13th ed, Sweet \& Maxwell, London, 2010) at [11-160]; Beatson, Burrows and Cartwright, above n 82, at 433; MP Furmston Cheshire, Fifoot and Furmston's Law of contract (16th ed, Oxford University Press, Oxford, 2012) at 529.

149 Attwood v Lamont [1920] 3 KB 571 (CA) at 578 per Lord Sterndale MR; Peel, above n 148, at [11161]; Beatson, Burrows and Cartwright, above n 82, at 435.
} 
c) Severance must not alter the nature of the agreement. ${ }^{150}$

d) The promise to be severed must not be substantially the whole consideration for the other party's enforceable promise. ${ }^{151}$

Criteria (b) and (c) are perceived by some authors to only apply in cases of severance where a promise is to be reduced instead of being entirely eliminated from a contract. ${ }^{152}$ But with regard to criterion (c), this view seems impossible to reconcile with the more recent cases of Hashwani, Carney and Carr, where the courts asked whether the nature of the agreement would be changed. ${ }^{153}$

Agreeing on appeal rights is neither a crime nor immoral - thus, the first requirement will generally be met. The "blue pencil" test should normally be satisfied, too-at least in the cases that have become public no contract reformation was necessary. ${ }^{154}$ The main emphasis in cases concerning appeal agreements will therefore usually lie on the requirements (c) and (d).

But the test (d) of whether the promise is substantially the whole consideration for the other party's enforceable promise is in this author's opinion not useful when examining appeal clauses. As stated above, an appeal clause is, as a matter of principle, neutral. ${ }^{155}$ That is to say both parties promise each other the same: to allow an appeal from the arbitration award. Both parties' consideration is thus contained in the very same clause, both parties lose exactly the same consideration through severance of said clause, and there remain, at the very least, still the promises to arbitrate from both parties. It is

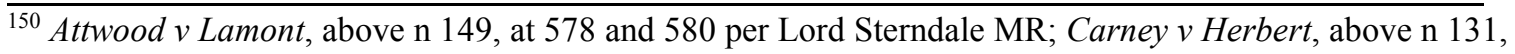
at 310 and 316; Peel, above n 148, at [11-164]; Beatson, Burrows and Cartwright, above n 82, at 436.

151 Bennett v Bennett, above n 148, at 261; Goodinson v Goodinson, above n 148, at 123/124; Marshall v NM Financial Management Ltd, above n 128, at 1532; Man Financial (S) Pte Ltd (formerly known as E D \& F Man International (S) Pte Ltd) v Wong Bark Chuan David [2007] SGCA 53, [2008] 1 SLR 663 at [128]; Furmston, above n 148, at 530; Beatson, Burrows and Cartwright, above n 82, at 435-436; Peel, above $\mathrm{n} 148$, at [11-153].

${ }^{152}$ See Furmston, above n 148, at 531-534; John Burrows, Jeremy Finn and Stephen Todd Law of contract in New Zealand (4th ed, LexisNexis NZ, Wellington, 2012) at 537.

${ }^{153}$ See Carney v Herbert, above n 131, at 316; Hashwani v Jivraj [2010] EWCA Civ 712, [2010] Bus LR 1683 at [31]; Carr v Gallaway Cook Allan, above n 36, at [67]-[72].

154 See Kyocera Corp v Prudential-Bache Trade Services, Inc, above n 47, at 990-991; Little v Auto Stiegler, Inc 63 P 3d 979 (Cal 2003) at 982-983; Carr v Gallaway Cook Allan, above n 36, at [67].

${ }^{155}$ See above IV.A. 
therefore a given in such cases that requirement (d) is met; this test amounts to an empty formula and should accordingly not be applied.

In addition, one might look at it differently: In jurisdictions with opt-in statutes such as the United Kingdom and New Zealand ${ }^{156}$, an appeal clause could be regarded as too wide a promise because the parties to an arbitration agreement can only opt for appeals on questions of law (instead of appeals on questions of law and facts). Accordingly, the appeal clause would not need to be eliminated entirely but only to be reduced. This too would result in applying criterion (c) rather than (d).

It is therefore no surprise that the Courts concerned with unenforceable clauses in arbitration agreements rather inquired into the effect of severance on the nature of the agreement than into the parties' considerations. ${ }^{157}$ This also seems to be the approach favoured by Gary B Born who submits: ${ }^{.58}$

The proper analysis in such cases is one of ascertaining the parties' intentions: was the parties' intention to arbitrate their disputes altered or undone by virtue of the invalidation or ineffectiveness of one term of their agreement to arbitrate.

The Singapore Court of Appeal recently held in Man Financial that the English position on the doctrine of severance represented the current Singapore position. ${ }^{159}$ The Court formulated the basic test concerning the severance of entire clauses in a contract as whether the objectionable promise "is substantially the whole or the main consideration for the promise sought to be enforced"160, thus applying criterion (d). This is, as stated above, not the current English position anymore and, most of all, not an appropriate test of severability for appeal clauses. It is doubtful if Singapore courts, when concerned with unenforceable clauses in arbitration agreements, would follow Man Financial.

\footnotetext{
${ }^{156}$ See above II.C.

${ }^{157}$ See Hashwani v Jivraj, above n 153, at [31]; Carr v Gallaway Cook Allan, above n 36, at [67]-[72].

${ }^{158}$ Gary B Born International Commercial Arbitration (Wolters Kluwer Law \& Business, Austin, 2014) vol 1 at 914.

${ }^{159}$ Man Financial (S) Pte Ltd (formerly known as E D \& F Man International (S) Pte Ltd) v Wong Bark Chuan David, above n 151, at [129].

${ }^{160}$ At [128].
} 


\section{The English case of Hashwani v Jivraj}

In the recent case of Hashwani ${ }^{161}$ the Court of Appeal of England and Wales had to examine an arbitration agreement prescribing that all members of the tribunal be members of the Ismaili community (a branch of Islam). ${ }^{162}$ The Court held that this clause was in violation of the applicable employment law. ${ }^{163}$ Applying the aforementioned principles, the Court noted that the "blue pencil" test was easily satisfied as just one sentence needed to be struck out. ${ }^{164}$ Severance, however, was only possible "if it does not render that which remains substantially different from that which the parties originally intended." 165 In this respect the Court observed that the ability to influence the composition of the arbitral tribunal through the appointment of its members was often viewed of fundamental importance. The Court therefore found that the clause formed an integral part of the arbitration agreement und could accordingly not be severed. ${ }^{166}$ It should be noted in this regard that this case is an example of an examination before the arbitration.

Upon appeal, the Supreme Court held that the employment law provisions considered by the Court of Appeal did not apply to the clause in dispute; accordingly, the entire arbitration agreement was valid. ${ }^{167}$ The Supreme Court therefore did not examine the question of severability. ${ }^{168}$

The approach of the Court of Appeal on severability has been criticised. Some commentators submitted that the issue should have been resolved applying the doctrine of separability. ${ }^{169}$ As has been explained above, this paper favours restricting the application of the doctrine of separability to cases where the main contract is invalid. ${ }^{170}$

\footnotetext{
${ }^{161}$ Hashwani v Jivraj, above n 153.

162 At [2].

${ }^{163}$ At [30].

${ }^{164}$ At [31].

${ }^{165}$ At [31].

166 At [34].

${ }^{167}$ Hashwani v Jivraj [2011] UKSC 40 at [50].

${ }^{168}$ At [72].

169 Oseni and Kadouf, above n 72, at 542.

${ }^{170}$ See above III.B.
} 
Another commentator suggested, "where the overwhelming objective of a defective clause is to have disputes resolved by arbitration", the court should "simply excise the objectionable provision". ${ }^{171}$ This is not substantially different from the approach of the Court of Appeal: It is simply a matter of framing the "overwhelming objective" or character or nature of the contract-here: the arbitration agreement. While that commentator defined the overwhelming objective of the agreement as "to have disputes resolved by arbitration", the Court found the overwhelming objective was to have disputes resolved by Ismaili arbitrators.

This author thinks that it is difficult to judge without having knowledge of the facts of the case. However, the absence of a clause empowering the tribunal to act ex aequo et bono or apply anything else than English law ${ }^{172}$ seems to indicate that the religion of the arbitrators might not have been so central to the agreement such as to prevent severance.

\section{The New Zealand case of Carr v Gallaway Cook Allan}

In the more elaborate decision in Carr v Gallaway Cook Allan, the Supreme Court of New Zealand ultimately followed the same approach. In this case, the parties had entered into an arbitration agreement to refer their differences to a sole arbitrator "whose award shall be final and binding on the parties (subject to clause 1.2)." ${ }^{173}$ Clause 1.2 of the agreement provided for appeals on ,questions of law and fact ${ }^{\text {“ }}{ }^{174}$

In a partial award the arbitrator had dismissed Mr Carr's claim. The High Court allowed Mr Carr's application to set aside the award as it found that the agreement was entirely invalid under the law of New Zealand due to the clause on appeals. ${ }^{175}$ The Court applied an approach formulated by the Full Court of the Supreme Court of Victoria in Brew v. Whitlock (No.2) ${ }^{176}$ as adopted by the High Court of Australia in Humphries ${ }^{177}: 178$

\footnotetext{
171 Samuel Adam "Discrimination: Should the Debate end despite the Decision on Jivraj v Hashwani?" [2011] 4 The Resolver 8 at 8.

172 See Hashwani v Jivraj, above n 153, at [29].

${ }^{173}$ Carr v Gallaway Cook Allan, above n 36, at [8].

${ }^{174}$ At [8].

${ }^{175}$ Carr v Gallaway Cook Allan, above n 142.

${ }^{176}$ Brew v Whitlock (No 2) [1967] VicRp 102, (1967) 1967 VR 803 (SC Full Court).

177 Humphries v Proprietors “Surfers Palms North” Group Titles Plan 1955 [1994] HCA 21, (1994) 179 CLR 597 (HCA) at [38] per McHugh J.
} 
In that case the Full Court said that ... "once the conclusion is reached that the invalid promise is so material and important a provision in the whole bargain that there should be inferred an intention not to make a contract which would operate without it", the invalid promise should be treated as inseverable from the contract.

Gallaway Cook Allan then appealed against the High Court's judgment. The Court of Appeal allowed their appeal and set aside the High Court's judgment. ${ }^{179}$ The Court interpreted the analysis of the High Court as a "but for"-test and rejected it, citing Carney $v$ Herbert. ${ }^{180}$ The Court found that the right of appeal was merely ancillary, whereas the primary consideration passing from each party was the agreement to submit to arbitration, which had been fully performed. ${ }^{181}$

Upon appeal by Mr Carr, the Supreme Court of New Zealand reinstated the High Court's judgment setting aside the arbitral award. ${ }^{182}$

Having examined the approaches applied in Carney $^{183}$,Humphries $^{184}$ and Kyocera ${ }^{185}$, the Supreme Court summarized the principles of severability as follows: ${ }^{186}$

The overall approach to severability that emerges from these decisions is one that is founded on core contractual principles. The significance of severance of an invalid contractual provision is evaluated in the course of examination of what the parties are to be taken to have agreed in the words they used. This is an issue of construction of the contract. It is likely to be permissible to sever an invalid promise which is subsidiary to the main purpose of the contract, but severance may not destroy the main purpose and substance of what has been agreed. Severance cannot be permitted to alter the nature of a contract.

The Court found that the approach applied in Humphries-to assess "whether a provision was so material and important to the parties' bargain that no intention could be

${ }^{178}$ Carr v Gallaway Cook Allan, above n 142, at [40].

179 Gallaway Cook Allan v Carr [2013] NZCA 11, [2013] 1 NZLR 826 (CA).

${ }^{180}$ At [29].

${ }^{181}$ At [48].

${ }^{182}$ Carr v Gallaway Cook Allan, above n 36.

${ }^{183}$ Carney v Herbert, above n 131.

${ }^{184}$ Humphries v Proprietors "Surfers Palms North" Group Titles Plan 1955, above n 177, at [38] per McHugh J.

${ }^{185}$ Kyocera Corp v Prudential-Bache Trade Services, Inc, above n 47.

${ }^{186}$ Carr v Gallaway Cook Allan, above n 36, at [62] (footnotes omitted). 
inferred to enter a contract without it" ${ }^{\prime 187}$ — was based on objective manifestation of contractual intentions and did not involve a subjective inquiry. It was therefore not a "but for"-test: ${ }^{188}$

The approach is one way of establishing whether applying the doctrine of severance would leave the subject matter of the contract and the primary obligations of the parties unchanged: it is an expression, in different words, of the first stage of inquiry into the severability referred to in Carney.

The Court then turned to applying this test to the case in point: ${ }^{189}$

[68] The nature of the transaction entered into by the parties was to submit their dispute to the award and decision of the nominated arbitrator for final and binding determination, with an important reservation concerning their agreement that the arbitrator's award would be final. The submission of the dispute to arbitration was stated to be subject to $\mathrm{cl} 1.2$, being the term that provided for appeal on questions of law and fact. The parties' mutual undertaking to carry out any award without delay was also subject to that qualification in $\mathrm{cl} 1.2$....

[69] Whether this provision goes to the very nature of their contract (and not merely its extent), and whether it was so material and important a provision in their agreement to submit the dispute to arbitration that objectively there should be inferred an intention not to submit the dispute to arbitration without it, is really the same issue. It is an issue of construction of their contract.

[70] In the present case, the parties indicated in their agreement to arbitrate the degree of importance that they attributed to the scope of their ability to challenge the award on appeal. Their italicisation of the words "questions of law and fact", followed by the notation "(emphasis added)" made clear, objectively, that the scope of the appeal right did go to the heart of their agreement to submit their dispute to arbitration. ... While that may not always be the position with a provision in an arbitration agreement that purports to expand recourse to the courts from what the Act permits, it is undoubtedly so in this instance. The dispute was submitted to arbitration on this basis.

A minority of the Court dissented on grounds of art 34(2)(a)(iv) of sch 2 of the Arbitration Act 1996. This provision allows setting aside an award "if the arbitral procedure was not in accordance with the agreement of the parties", except if the agreement was in conflict with a provision of sch 2 of the Arbitration Act 1996 "from

\footnotetext{
${ }^{187}$ At [65].

${ }^{188}$ At [66].

${ }^{189}$ Carr v Gallaway Cook Allan, above n 36.
} 
which the parties cannot derogate". ${ }^{190}$ The minority argued that deviation from the appeal agreement was accordingly not a sufficient ground to set aside the award, as the parties are not allowed to contractually opt for an appeal: ${ }^{191}$

[I]f parties choose to utilise arbitration to resolve their disputes, they will be treated as being bound by those aspects of the arbitral process from which they cannot legally derogate whatever they might agree.

To summarize the majority of the Court's findings, it held that the appeal clause- due to the obvious emphasis the parties had placed on it-went to the very nature of the arbitration agreement. ${ }^{192}$ Deleting it would accordingly alter the nature of the agreement-hence, severance was not possible. The Court was apparently cautious to confine its judgment to the rather extraordinary facts presented to it.

\section{Appraisal of the Commonwealth test}

In this author's submission, it is in the nature of arbitration agreements that the result of this test of severability must be the same in almost every case concerning appeal agreements, for the following reason:

Arbitration is not just another form of litigation that starts in a tribunal instead of a court, a mere ,prelude to a more cumbersome and time-consuming judicial review process“". ${ }^{193}$ As Gary B Born puts it: "One of the most fundamental purposes of the arbitral process is to obtain a speedy, final resolution of the parties' disputes, without the costs and delays of litigation." 194 Consequently, the finality of the arbitral award is widely regarded as one of the key features of arbitration both by legal scholars ${ }^{195}$ and (according

\footnotetext{
${ }^{190}$ Arbitration Act 1996, art 34(2)(a)(iv) of sch 2.

${ }^{191}$ Carr v Gallaway Cook Allan, above n 36, at [106] per Arnold J dissenting.

${ }^{192}$ An interesting issue not addressed by the Court (see at 22-23) is the possible inconsistency between its approach and the Contractual Mistakes Act 1977, which did not provide a remedy in the case at hand for lack of a substantially unequal exchange of values at the time of the contract (see Contractual Mistakes Act 1977, s 6(1)(b)).

${ }^{193}$ Kyocera Corp v Prudential-Bache Trade Services, Inc, above n 47, at 998.

${ }^{194}$ Born, above $\mathrm{n} 26$, at 2512.

${ }^{195}$ See Born, above n 8, at 81; Blackaby and others, above n 1, at [1.02]; Sutton, above n 30, at [1-015]; Greenberg, Kee and Weeramantry, above n 6, at [183]; Hall Street Associates, LLC v Mattel, Inc, above $\mathrm{n}$ 25 , at 588 (“arbitration's essential virtue of resolving disputes straightaway").
} 
to a 2006 study among major international corporations $)^{196}$ by most parties to international arbitration agreements ${ }^{197}$.

When parties submit their dispute to arbitration, while retaining full rights of appeal to the courts, then it can hardly be said that they have consented to real arbitration. Rather, it seems, they had in mind, and thus contracted for, a trial of first instance in a different procedural setting. Against this background, it is, in this author's view, fair to say that eliminating an appeal clause from an arbitration agreement changes the very nature of the arbitration agreement.

But this paper ventures to submit that the result should not be determined by this test alone in all cases. The test is reasonable on its own if a decision is reached before the start of the arbitration because it leaves the parties with the opportunity to nevertheless agree on arbitration. If, however, the arbitration process is already finished and an award has been rendered, then the parties cannot anymore simply evaluate the advantages and disadvantages of arbitration against litigation. They already know the outcome of arbitration, and at least one of the parties will be dissatisfied with it. Therefore, the parties do not have a fair chance anymore to agree on arbitration - unless on a new arbitration, which however makes no sense in terms of allocation of resources.

Against this background, the change of the nature of the arbitration agreement through severance should not be enough to refrain from it. Rather, an additional requirement should be established in such cases to make up for the parties' lost chance to opt for arbitration: the "but for"-test. The arbitration agreement should only then be invalidated when it can be shown that at the time the parties would not have agreed on arbitration absent the appeal clause. Taking into account the pro-arbitration policy, which the laws of New Zealand ${ }^{198}$ the United Kingdom ${ }^{199}$ and Singapore ${ }^{200}$ have in common,

\footnotetext{
196 See Rowan Platt "The Appeal of Appeal Mechanisms inInternational Arbitration: Fairness over Finality?” (2013) 30 J Int'l Arb 531 at 531-532.

197 At 532: "An overwhelming majority of those interviewed perceived the availability of an appeal mechanism to be a disadvantage, because it would make arbitration more "cumbersome and litigation-like and essentially negate a key attribute of the arbitral process'- the finality of arbitral awards."

${ }^{198}$ See Arbitration Act 1996 s 5(a).

${ }^{199}$ See Arbitration Act 1996 (UK), s 1(c).

${ }^{200}$ See International Arbitration Act 1994 (SG), art 5 of sch 1.
} 
the burden of proof should lie with the party seeking to invalidate the arbitration agreement.

The hypothetical outcome of a "but for"-test in Carr remains obscure. It is noteworthy though that Gallaway Cook Allan, not Mr Carr, had brought up the idea of the rights of appeal. ${ }^{201}$ While Mr Carr instantly agreed to the idea, ${ }^{202}$ it is unclear whether Gallaway Cook Allan would have insisted on an appeal clause, as both parties must have been interested in keeping the dispute secret.

\section{The test of interconnectedness of the valid and invalid clauses}

\section{The basic test}

When determining if an illegal clause may be severed from a contract, United States courts often ask whether legal and illegal contractual provisions are integrated and interdependent. ${ }^{203}$ The inquiry is to determine if the parties' promises can each be divided and apportioned into corresponding pairs. ${ }^{204}$

Under Virginia law, "when a contract covers several subjects, some of whose provisions are valid and some void, those which are valid will be upheld if they are not so interwoven with those illegal as to make divisibility impossible". ${ }^{205}$ The Court's assessment of the provisions as being interwoven with one another often means nothing else but that the court inquires into whether they are supported by a separate consideration: Thus, in Alston Studios the illegal provision, an excessive restraint of trade, could not be severed without severing the clause containing the compensation for the covenant not to compete. ${ }^{206}$

The same holds true for Kentucky where the general rule is that severance is permitted if the illegal covenant can be eliminated from the contract without impairing its

\footnotetext{
${ }^{201}$ See Carr v Gallaway Cook Allan, above n 142, at [6].

${ }^{202}$ See at [7].

203 Zell, above n 85, at 969.

${ }^{204}$ Farnsworth, above $\mathrm{n} 83$, at 381-382.

${ }^{205}$ City of Bristol v Dominion National Bank 149 SE 632 (Va 1929) at 636; Alston Studios, Inc v Gress \& Associates 492 F 2d 279 (1974) at 285.

${ }^{206}$ Alston Studios, Inc v Gress \& Associates, above n 205, at 285.
} 
symmetry as a whole and without altering or destroying the general meaning and purpose of the contract. ${ }^{207}$ In Edleson severance was allowed because the illegal provision was said to carry its own consideration rather than constitute any consideration for any other provision of the contract: ${ }^{208}$

Its elimination will not impair the contract, as a whole, or in anywise affect any other provision of it, and hence might be properly considered an independent covenant carrying with it the relief for its breach independently of the performance or nonperformance of any other covenant in the contract.

The position prevailing in Kentucky was adopted in Indiana. ${ }^{209}$ Accordingly, a provision for confession of judgment contained in a sale contract was held to be severable because it could be eliminated ,without destroying the symmetry as a whole“ ${ }^{210}$

In Florida the test is if "the illegal portion of the contract does not go to its essence", and if "there still remains of the contract valid legal promises on one side which are wholly supported by valid legal promises on the other." 211 The Supreme Court of Florida applied this standard when examining arbitration agreements that contained an illegal provision in the cases Shotts ${ }^{212}$ and Gessa ${ }^{213}$. In Shotts, the arbitration agreement provided, inter alia, that the arbitration be conducted in accordance with the arbitration rules of the American Health Lawyers Association ("AHLA"), which the Court found to be in violation of public policy. ${ }^{214}$ The Court held that the AHLA provision went ,to the very essence of the agreement." Severance would require the Court "to rewrite the agreement and to add an entirely new set of procedural rules and burdens and standards, a

\footnotetext{
${ }^{207}$ Edleson v Edleson 200 SW 625 (Ky App 1918) at 629.

208 At 630.

209 Jordan v Kittle 150 NE 817 (Ind App 1926) at 822; Corner v Mills 650 NE 2d 712 (Ind App 1995) at 715.

${ }^{210}$ Crescent City Aviation, Inc v Beverly Bank 219 NE 2d 446 (Ind App 1966) at 676.

211 Local No 234 of United Association of Journeymen and Apprentices of Plumbing and Pipefitting Industry of United States and Canada v Henley \& Beckwith, Inc 66 So 2d 818 (Fla 1953) at 821-822.

212 Shotts v OP Winter Haven, Inc 86 So 3d 456 (Fla 2011).

${ }^{213}$ Gessa v Manor Care of Florida, Inc 86 So 3d 484 (Fla 2011).

214 Shotts v OP Winter Haven, Inc, above n 212, at 474.
} 
job that the trial court is not tasked to do." ${ }^{215}$ Further, the Court noted it would be hard pressed to find that there still remained of the contract valid legal promises. ${ }^{216}$

The offending clause in Gessa provided for a limitation of liability. The majority of the Court held that this provision constituted the "financial heart of the agreement". ${ }^{217}$ It found that there would not remain of the contract valid legal promises, and therefore the provisions were not severable. ${ }^{218}$ A minority disagreed, holding that the financial heart of the agreement was instead to be found in the main agreement, whereas the arbitration agreement was a side agreement, determining the specifics of arbitration. There would have remained enough of it even after the illegal provision had been eliminated since the parties had agreed on a set of rules governing the arbitration including procedural rules, provisions on arbitrator's and attorneys' fees. ${ }^{219}$

This author submits that Gessa should have been solved by applying the rule of separability $^{220}$ instead of the doctrine of severance: The provisions on limitations of liability did in substance not form part of the agreement to arbitrate because they were not merely a limitation of powers of the arbitrator but a general limitation of liability, ${ }^{221}$ even though they were "incorporated by reference" into the arbitration agreement. ${ }^{222}$

Where the test of severability consists in examining if enough valid promises remain of the contract, the test is essentially equal to the old Commonwealth requirement that the promise to be severed must not be substantially the whole consideration for the other party's enforceable promise. It has been shown above that this test is not suited for arbitration agreements. $^{223}$

\footnotetext{
215 At 478 .

${ }^{216}$ At 478 .

${ }^{217}$ Gessa v Manor Care of Florida, Inc, above n 213, at 490.

${ }^{218}$ At 490-491.

${ }^{219}$ At 497-498 per Polston J and Canady CJ dissenting.

${ }^{220}$ See above III.B.

${ }^{221}$ See Born, above $\mathrm{n} 8$, at $729 \mathrm{n} 850$ : "It is doubtful that provisions affecting the parties' substantive rights and legal remedies should be considered relevant to the validity of the agreement to arbitrate. Rather, these should be treated as issues of substantive law, ..."

${ }^{222}$ See Gessa v Manor Care of Florida, Inc, above n 213, at 488.

${ }^{223}$ See above IV.B.1.
} 
The same holds true for tests of whether the illegality permeates other parts of the agreement or whether the clause is interdependent with other provisions. Those are inappropriate tests because they will result in severance in virtually all cases, ${ }^{224}$ without taking into account if the remaining contract is materially changed or if the parties had concluded the contract nevertheless.

\section{The Californian inquiry into the interests of justice}

The bulk of judgments on severability of appeal clauses in the United States was rendered applying Californian law. The Supreme Court of California summarized the basic principles of severance in Armendariz: ${ }^{225}$

Courts are to look to the various purposes of the contract. If the central purpose of the contract is tainted with illegality, then the contract as a whole cannot be enforced. If the illegality is collateral to the main purpose of the contract, and the illegal provision can be extirpated from the contract by means of severance or restriction, then such severance and restriction are appropriate.

Thus, the test of severability is in principle the same as in most States. However, when concerned with illegal provisions in arbitration agreements, Californian courts additionally examine whether the interests of justice would be furthered by severance. ${ }^{226}$

\section{a) The original purpose of the inquiry}

The inquiry as to the interests of justice was established in Armendariz $^{227}$, citing Beynon $^{228}$. Beynon was a rather extraordinary case, in which the defendants had imposed a provision (paragraph B) that gave them the right to reject any arbitral award. ${ }^{229}$ The arbitrators awarded the plaintiff USD 60,000 in damages. The defendants rejected the award, whereas the plaintiff moved to confirm the award. The Court of Appeal found that paragraph B violated public policy and was invalid. It then turned to the question of severance and cited a commentator's note: ${ }^{230}$

\footnotetext{
${ }^{224}$ But see Shotts v OP Winter Haven, Inc, above $\mathrm{n} 212$.

${ }^{225}$ Armendariz v Foundation Health Psychcare Services, Inc 6 P 3d 669 (Cal 2000) at 696.

${ }^{226}$ Zell, above n 85, at 969.

${ }^{227}$ Armendariz v Foundation Health Psychcare Services, Inc, above n 225, at 696.

${ }^{228}$ Beynon v Garden Grove Medical Group, above $\mathrm{n} 141$.

${ }^{229}$ See at $704, \mathrm{n} 2$.

${ }^{230}$ At 713 .
} 
Mr Witkins notes that "later California cases take a very loose view of severability, enforcing valid parts of an apparently indivisible contract where the interests of justice or the policy of the law (as the court conceives it) would be furthered."

However, the reasoning of the Court did not refer to the interests of justice. The Court simply held that paragraphs $\mathrm{A}$ and $\mathrm{C}$ constituted a complete and valid arbitration agreement and where thus "clearly severable from and untainted by the provisions of paragraph B". ${ }^{231}$ Similarly, in later cases no reference was made to the interests of justice until it all of a sudden became the "overarching inquiry" in Armendariz. ${ }^{232}$

The Armendariz court was confronted with a one-sided arbitration clause in an employment contract, which only required the employee to arbitrate and precluded several forms of damages. ${ }^{233}$ The Court noted that two reasons for severing illegal clauses appeared in case law: ${ }^{234}$

The first is to prevent parties from gaining undeserved benefit or suffering undeserved detriment as a result of voiding the entire agreement - particularly when there has been full or partial performance of the contract. Second, more generally, the doctrine of severance attempts to conserve a contractual relationship if to do so would not be condoning an illegal scheme. The overarching inquiry is whether "the interests of justice ... would be furthered" "by severance.

The Court then held that the agreement contained more than one unlawful provision and that therefore it was not possible to strike a single provision in order to remove the unconscionable taint from the agreement. ${ }^{235}$

Regarding the furthering of the interests of justice the Court observed that not severing the provisions in Beynon would have exactly fulfilled the illegal purpose of these provisions: to allow the defendants to invalidate the arbitration award. ${ }^{236}$ In Armendariz on the other hand, no such situation was present as the plaintiffs, on whom the unconscionable provisions had been imposed, had initiated court proceedings instead

\footnotetext{
231 At 713.

232 Armendariz v Foundation Health Psychcare Services, Inc, above n 225, at 696.

233 At 675 .

${ }^{234}$ At 696 (citations omitted).

${ }^{235}$ At 696-697.

${ }^{236}$ At 698-699.
} 
of arbitration. ${ }^{237}$ Thus, while the interests of justice had required severance in Beynon, they did not in Armendariz.

\section{b) Recent case law on the inquiry}

In Little $^{238}$ the Supreme Court of California had to rule on an arbitration agreement containing an effectively one-sided appeal clause providing for arbitral review. The Court, applying the principles set out in Armendariz, found that the appeal clause was the only unconscionable provision and could be severed leaving the rest of the arbitration agreement intact. Thus, no contract reformation was required. ${ }^{239}$ While the interests of justice were not mentioned, the Court remarked that the provision had not been drafted in bad faith. ${ }^{240}$

The Second District Court of Appeal of California examined an appeal clause in an arbitration agreement in Crowell and found it to be invalid. ${ }^{241}$ The Court stated. ${ }^{242}$

The provision for judicial review of the merits of the arbitration award was so central to the arbitration agreement that it could not be severed. To do so would be to create an entirely new agreement to which neither party agreed. ... The parties to the contract here agreed to arbitration with judicial review of errors of law and fact. Without that provision, a different arbitration process results.

It should be noted that the plaintiff had, in a complaint for declaratory relief, sought a judicial determination that the arbitration agreement was valid and enforceable. ${ }^{243}$ The Court therefore rendered its judgment before arbitration proceedings had been initiated.

Later that year, the First District Court of Appeal of California had to decide the case of Oakland-Alameda County Coliseum Authority v CC Partners, which, too, involved an arbitration agreement containing an appeal clause. ${ }^{244}$ The Oakland-Alameda court

\footnotetext{
${ }^{237}$ See at $674-675$.

${ }^{238}$ Little v Auto Stiegler, Inc, above n 154.

${ }^{239}$ At 986.

${ }^{240}$ At $986-987$.

${ }^{241}$ Crowell v Downey Community Hospital Foundation 115 Cal Rptr 2d 810 (Cal App 2002).

${ }^{242}$ At 817.

${ }^{243}$ At 812 .

244 Oakland-Alameda County Coliseum Authority v CC Partners 124 Cal Rptr 2d 363 (Cal App 2002) at 370 .
} 
distinguished Crowell in two ways: First, the arbitral award had already been rendered. ${ }^{245}$ Accordingly, the Court held that CC Partners would gain an undeserved benefit if the entire arbitration agreement were struck "when the arbitration itself suffered from no infirmity". ${ }^{246}$ Second, the agreement in point contained a severance clause. ${ }^{247}$

In the famous Kyocera decision, an arbitration agreement with an appeal clause was brought before the $9^{\text {th }}$ Circuit Court of Appeal. ${ }^{248}$ Applying Californian contract law, the Court found that the appeal clause should be severed. ${ }^{249}$ It noted that, as in Little, no contract reformation was required, the illegality did not permeate any other part of the arbitration clause and the appeal provisions were not interdependent with any other. ${ }^{250}$ It also held that the scope of judicial review was "not sufficiently central to the arbitration clause to defeat severability." 251 With regard to the interests of justice, the Court cited Oakland-Alameda and found that Kyocera would gain an undeserved benefit if the entire arbitration agreement were struck after the arbitration had been conducted impeccably. ${ }^{252}$

The same court later applied Kyocera in Hall Street Associates ${ }^{253}$, a case from Oregon, holding that the evidence that the parties would not have concluded the arbitration agreement absent the appeal clause was "not strong enough to distinguish this case from Kyocera". ${ }^{254}$ The case was brought before the Supreme Court. ${ }^{255}$ While Hall Street did not seek certiorari on the severance point, ${ }^{256}$ nothing in the Supreme Court's decision indicates that it disagreed with the analysis.

\footnotetext{
245 At 371 .

246 At 372.

247 At 371.

${ }^{248}$ Kyocera Corp v Prudential-Bache Trade Services, Inc, above n 47.

${ }^{249}$ Kyocera Corp v Prudential-Bache Trade Services, Inc, above n 47.

${ }^{250}$ At 1001-1002.

251 At 1002 .

252 At 1002.

${ }^{253}$ Hall Street Associates, LLC v Mattel, Inc 113 Fed Appx 272 (9th Cir 2004).

254 At 273.

255 See Hall Street Associates, LLC v Mattel, Inc, above n 25.

256 At 587, n 6.
} 


\section{c) Appraisal of the inquiry}

The overview of the Californian case law suggests that the inquiry as to the interests of justice originally (in Beynon, Little and Armendariz) functioned as an estoppel against a party's unfair invocation of the entire arbitration agreement's invalidity. Moreover, it was closely linked to the question of who had drafted and would benefit from the invalid clause (given that more often than not the invalid clauses were one-sided). It was only in Oakland-Alameda and Kyocera that the Court applied it in a broader sense. And it seems to this author that the inquiry in these two cases was somewhat misguided. ${ }^{257}$ In this author's opinion, the inquiry should be reserved for cases similar to the ones for which it had been established.

Certainly, the courts were right in holding that Kyocera or CC Partners would gain an undeserved benefit if the whole of the parties' arbitration agreement were to be found invalid "when the arbitration itself suffered from no infirmity"258. The courts failed to mention, though, that things would be entirely different if the arbitration did in fact suffer from an infirmity, especially from one that would have been likely to be corrected upon appeal. In such a case, it would of course be the counterparty that gained an undeserved benefit if only the appeal clause were to be found invalid. To determine which is true would, however, require the court to do exactly what legislation precludes it from doing: to assess whether the award contained errors of law or fact.

The reason for the courts expanding the interests of justice-test was in this author's submission the shortcoming of the Californian test of severability with regard to appeal clauses. The basic test of severability, as explained above, examines if the illegality is collateral to the main purpose of the contract, and the illegal provision can be extirpated from the contract by means of severance or restriction. ${ }^{259}$ This is an examination of the contract's construction, that is to say: of the form rather than the substance of the

\footnotetext{
257 But see Eric van Ginkel “Expanded’ Judicial Review Revisited: Kyocera Overturns LaPine” 4 Pepp Disp Resol L J 47 at 12 (arguing the Kyocera court should have made this the principal ground for severance).

258 Oakland-Alameda County Coliseum Authority v CC Partners, above n 244, at 372; Kyocera Corp v Prudential-Bache Trade Services, Inc, above n 47, at 1002.

259 Armendariz v Foundation Health Psychcare Services, Inc, above n 225, at 696.
} 
contract. While the test puts much emphasis on contract construction, it neither analyses whether the nature of the contract would be changed through severance nor whether the parties would have entered into the agreement absent the clause to be severed.

The latter two elements however should, in this author's opinion, be the heart of any test of severability. The appropriate test of severance in arbitration agreements consists of two elements, which can be phrased as the following two questions: Does it make a difference if the illegal part is deleted? And if so, would the parties have concluded the contract anyway? In legal terms, this means combining the test examining the effect of severance on the nature of the contract, as it is known in the Commonwealth, and the "but for"-test in its pure form. Only if neither of the two conditions can be satisfied should the entire arbitration agreement be invalidated. ${ }^{260}$

\section{Conclusions}

Appeal clauses in arbitration agreements raise a conflict between two of international arbitration's most powerful principles: the autonomy of the parties and the finality of the award. When striking a balance between these two principles, the jurisdictions examined in this paper have-with some limited exceptions - clearly favoured the finality of the award.

Thus, the validity of appeal agreements has either been denied by the courts or is very doubtful as appeal agreements interfere with statutory provisions aimed at protecting the finality of arbitral awards.

However, the question of whether this invalidates the remainder of the arbitration agreement has been answered in more diverse ways. The different tests that are applied in the jurisdictions examined (based either on the common law doctrine of severance or the civil law doctrine of partial nullity) can be divided into three main approaches. All three approaches have their own shortcomings.

Switzerland and some jurisdictions in the United States apply a "but for"-test, which inquires into whether the parties would have entered into the agreement without the

${ }^{260}$ See above IV.B.4. 
invalid clause. The "but for"-test inquires only into the subjective intentions of the parties, thus enabling the losing party to argue that it would not have entered into the agreement absent the eliminated clause, without having regard to the objective effect on the arbitration agreement.

The approach preferred in the Commonwealth permits severance unless it would alter the nature of the agreement. This test is persuasive regarding the objective element but lacks an element that inquires into the parties' readiness to agree without the eliminated clause. Thus, it deprives the parties of the chance to still uphold the arbitration agreement, if they would have done so prior to the arbitration.

The third approach, predominantly applied in the United States, puts the emphasis on the construction of the contract, allowing severance if the parties' promises can be divided into distinct obligations. The downside of this test is that it examines neither the effect on the content of the contract nor the subjective intentions of the parties. Since appeal clauses are by nature distinct from the agreement to arbitrate, this test will allow severance every time, regardless of whether the character of the agreement is altered or whether the parties would have concluded it nevertheless.

As has been shown, the inquiry most appropriate for appeal clauses in arbitration agreements is one that looks for the answers to the following two questions: whether the remaining agreement is still the same in its heart; and whether the parties would have concluded it nevertheless. The best inquiry in terms of the first question is the Commonwealth test. The second question is best answered by applying the "but for"-test in its pure form, that is to say: the "but for"-test looking into the subjective intentions of the parties.

Accordingly, a combination of the "but for"-test in its pure form and the test examining whether the nature of the agreement remains unaltered appears to be the appropriate test. 


\section{BIBLIOGRAPHY}

\section{PRIMARY SOURCES}

\section{A Cases}

1 New Zealand

Carr v Gallaway Cook Allan [2012] NZHC 1537, [2012] 3 NZLR 97 (HC).

Carr v Gallaway Cook Allan [2014] NZSC 75 (SC).

Gallaway Cook Allan v Carr [2013] NZCA 11, [2013] 1 NZLR 826 (CA).

2 Australia

Amoco Australia Pty Ltd v Rocca Bros Motor Engineering Co Pty Ltd [1975] AC 561 (PC).

Brew v Whitlock (No 2) [1967] VicRp 102, (1967) 1967 VR 803 (SC Full Court).

Carney v Herbert [1985] AC 301 (PC).

Humphries v Proprietors "Surfers Palms North" Group Titles Plan 1955 [1994] HCA 21, (1994) 179 CLR 597 (HCA).

3 France

Société de Diseno v Société Mendes [1995] Revue de l'Arbitrage 263 (Cour d'Appel de Paris).

4 Germany

Undisclosed $v$ undisclosed [2006] SchiedsVZ 103 (OLG Naumburg).

Undisclosed $v$ undisclosed [2007] 25 ASA Bulletin 810, [2008] 33 Yearbook Comm Arb'n 231 (BGH).

5 Singapore

Government of the Republic of the Philippines $v$ Philippine International Air Terminals Co, Inc [2006] SGHC 206, [2007] 1 SLR 278 (SGHC).

Man Financial (S) Pte Ltd (formerly known as E D \& F Man International (S) Pte Ltd) $v$ Wong Bark Chuan David [2007] SGCA 53, [2008] 1 SLR 663.

PT Asuransi Jasa Indonesia (Persero) v Dexia Bank SA [2006] SGCA 41, [2007] 1 SLR 597 (SGCA). 
PT Perusahaan Gas Negara (Persero) TBK v CRW Joint Operation [2010] SGHC 202, [2010] 4 SLR 672 (SGHC).

Wong Bark Chuan David v Man Financial (S) Pte Ltd [2007] SGHC 5, 2 SLR 22 (SGHC).

6 Switzerland

$A v B S A$ [1997] 124 III BGE/ATF 57.

$A A G v B N V$ [2003] 130 III BGE/ATF 66.

Football club Xv Y Sàrl [2011] 138 III BGE/ATF 29.

$X v A$ BGer 4C.156/2006, 17 August 2006.

$X v A A G$ [2005] 131 III BGE/ATF 467.

$Y v X[1984] 110$ Ia BGE/ATF 59.

7 United Kingdom

Alec Lobb (Garages) Ltd v Total Oil (Great Britain) Ltd [1985] 1 WLR 173 (CA).

Attwood v Lamont [1920] 3 KB 571 (CA).

Bennett v Bennett [1952] 1 KB 249 (CA).

Guangzhou Dockyards Co Ltd (formerly Guangzhou CSSC-Oceanline-GSW Marine Engineering Co Ltd) v Ene Aegiali I [2010] EWHC 2826, [2011] Lloyd's Rep 30 (Comm).

Marshall v NM Financial Management Ltd [1997] 1 WLR 1527 (UKCA).

Goodinson v Goodinson [1954] 2 QB 118 (CA).

Hashwani v Jivraj [2010] EWCA Civ 712, [2010] Bus LR 1683.

Hashwani v Jivraj [2011] UKSC 40.

8 United States

Alston Studios, Inc v Gress \& Associates 492 F 2d 279 (1974).

Armendariz v Foundation Health Psychcare Services, Inc 6 P 3d 669 (Cal 2000).

Beynon v Garden Grove Medical Group (1980) 100 Cal App 3d 698, 161 Cal Rptr 146.

Bowen v Amoco Pipeline Co 254 F 3d 925 (10th Cir 2001).

City of Bristol v Dominion National Bank 149 SE 632 (Va 1929). 
Corner v Mills 650 NE 2d 712 (Ind App 1995).

Crescent City Aviation, Inc v Beverly Bank 219 NE 2d 446 (Ind App 1966).

Crowell v Downey Community Hospital Foundation 115 Cal Rptr 2d 810 (Cal App 2002).

Edleson v Edleson 200 SW 625 (Ky App 1918).

Gessa v Manor Care of Florida, Inc 86 So 3d 484 (Fla 2011).

Hall Street Associates, LLC v Mattel, Inc 113 Fed Appx 272 (9th Cir 2004).

Hall Street Associates, LLC v Mattel, Inc 552 US 576.

Kyocera Corp v Prudential-Bache Trade Services, Inc 341 F 3d 987 (9th Cir 2003 en banc).

Hargrave v Canadian Valley Electric Cooperative, Inc 792 P 2d 50 (Okl 1990).

Jordan v Kittle 150 NE 817 (Ind App 1926).

Little v Auto Stiegler, Inc 63 P 3d 979 (Cal 2003).

Local No 234 of United Association of Journeymen and Apprentices of Plumbing and Pipefitting Industry of United States and Canada v Henley \& Beckwith, Inc 66 So 2d 818 (Fla 1953).

McFarland v Haby 589 SW 2d 521 (Tex Civ App 1979).

Munoz v Green Country Imports, LLC Distr Ct, ND Okl 12-CV-322-GKF-FHM, 3 October 2012.

Oakland-Alameda County Coliseum Authority v CC Partners 124 Cal Rptr 2d 363 (Cal App 2002).

Rent-A-Center, West, Inc v Jackson 561 US 63 (2010).

Rogers $v$ Wolfson 763 SW 2d 922 (Tex Ct App 1989).

Saika v Gold 56 Cal Rptr 2d 922 (Cal App 1996).

Shotts v OP Winter Haven, Inc 86 So 3d 456 (Fla 2011).

Stolt-Nielsen SA v AnimalFeeds International Corp (2010) 559 US 662.

Whiteside v Griffis \& Griffis, PC 902 SW 2d 739 (Tex App-Austin 1995).

Zerbetz v Alaska Energy Center 708 P 2d 1270 (Alaska 1985). 


\section{B Legislation}

1 New Zealand

Arbitration Act 1996.

Contractual Mistakes Act 1977.

2 Singapore

International Arbitration Act 1994 (SG).

3 Switzerland

Bundesgesetz über das Internationale Privatrecht 1987 (translation: Federal Act on the Private International Law).

Schweizerische Zivilprozessordnung 2011 (translation: Civil Procedure Code).

Obligationenrecht 1911 (translation: Code of Obligations).

4 United Kingdom

Arbitration Act 1996.

5 United States

Federal Arbitration Act.

\section{Treaties}

United Nations Convention on the Recognition and Enforcement of Foreign Arbitral Awards (1959) vol 330.

\section{SECONDARY SOURCES}

\section{A United Nations Materials}

Report of the United Nations Commission on International Trade Law on the work of its eighteenth session (A/40/17, annex I 1985).

Revised articles of the Model Law on International Commercial Arbitration of the United Nations Commission on International Trade Law, and the recommendation regarding the interpretation of article II, paragraph 2, and article VII, paragraph 1, of the Convention on the Recognition and Enforcement of Foreign Arbitral Awards 2006 (A/61/17(SUPP), Annex 1).

UNCITRAL Model Law on International Commercial Arbitration 1985 (A/40/17(SUPP), Annex I). 
United Nations Commission on International Trade Law UNCITRAL 2012 digest of case law on the Model Law on International Commercial Arbitration (United Nations, New York, 2012).

\section{B Books and Chapters in Books}

Beatson, Sir Jack, Burrows, Andrew and Cartwright, John Anson's law of contract (29th ed, Oxford University Press, Oxford, 2010).

Berg, Albert Jan van den The New York Arbitration Convention of 1958: Towards a Uniform Judicial Interpretation (Kluwer Law and Taxation, Deventer (Netherlands), 1981).

Bishop, R Doak, Coriell, Wade M and Campos, Marcelo Medina "The 'Null and Void' Provision of the New York Convention" in Emmanuel Gaillard and Domenico Di Pietro (eds) Enforcement of Arbitration Agreements and International Arbitral Awards: The New York Convention in Practice (Cameron May, London, 2008) 275.

Blackaby, Nigel, Partasides, Constantine, Redfern, Alan and Hunter, Martin Redfern and Hunter on International Arbitration (5th ed (student version), Oxford University Press, Oxford, 2009).

Born, Gary B International Commercial Arbitration (Wolters Kluwer Law \& Business, Austin, 2009) vol 1.

Born, Gary B International Commercial Arbitration (Wolters Kluwer Law \& Business, Austin, 2009) vol 2.

Born, Gary B International Commercial Arbitration (Wolters Kluwer Law \& Business, Austin, 2014) vol 1.

Burrows, John, Finn, Jeremy and Todd, Stephen Law of contract in New Zealand (4th ed, LexisNexis NZ, Wellington, 2012).

Farnsworth, E Allan Farnsworth on contracts (3rd ed, Aspen Publishers, New York, 2004).

Furmston, MP Cheshire, Fifoot and Furmston's Law of Contract (16th ed, Oxford University Press, Oxford, 2012).

Gaillard, Emmanuel and Savage, John Fouchard, Gaillard, Goldman On International Commercial Arbitration (Kluwer Law International, The Hague, 1999).

Greenberg, Simon, Kee, Christopher and Weeramantry, J Romesh International Commercial Arbitration: An Asia-Pacific Perspective (Cambridge University Press, New York, 2011). 
Holtzmann, Howard M and Neuhaus, Joseph E A guide to the UNCITRAL Model Law on International Commercial Arbitration (Kluwer Law and Taxation Publishers, Deventer (Netherlands), 1989).

Kamerling, Alexandra and Osman, Christopher Restrictive Covenants under Common and Competition Law (5th ed, Sweet \& Maxwell, London, 2007).

Kröll, Stefan and Kraft, Peter "§ 1059 - Application for Setting Aside" in Karl-Heinz Böckstiegel, Stefan Kröll and Patricia Nacimiento (eds) Arbitration in Germany: the Model Law in Practice (Kluwer Law International, Alphen aan den Rijn (The Netherlands), 2007).

Peel, Edwin The Law of Contract (13th ed, Sweet \& Maxwell, London, 2010).

Poudret, Jean-François and Besson, Sébastien Comparative Law of International Arbitration (2nd ed, Sweet \& Maxwell, London, 2007).

Sutton, David St John Russell on Arbitration (23rd ed, Sweet \& Maxwell, London, 2007).

Wagner, Gerhard "§ 1026 - Extent of Court Intervention” in Karl-Heinz Böckstiegel, Stefan Kröll and Patricia Nacimiento (eds) Arbitration in Germany: the Model Law in Practice (Kluwer Law International, Alphen aan den Rijn (The Netherlands), 2007).

\section{Journal Articles}

Adam, Samuel "Discrimination: Should the Debate end despite the Decision on Jivraj v Hashwani?" [2011] 4 The Resolver 8.

Beffa, Luca "Decision 4A_246/2011 or the Leniency of the Swiss Federal Tribunal Towards Pathological Clauses" (2012) 30 ASA Bull 169.

Franc, Laurence "Contractual Modification of Judicial Review of Arbitral Awards: The French Position” (1999) 10 Am Rev Int'l Arb 215.

Ginkel, Eric van “"Expanded’ Judicial Review Revisited: Kyocera Overturns LaPine” 4 Pepp Disp Resol L J 47.

Howell, David, Duthie, Leigh and Lim, Mark "International Arbitration in Singapore: Opting out of the UNCITRAL Model Law” (2002) 19 J Int'1 Arb 39.

Marsh, Norman S “The Severance of Illegality in Contract” 64 LQR 230.

Moses, Margaret "Can Parties Tell Courts What to Do? Expanded Judicial Review of Arbitral Awards" (2004) 52 U Kan L Rev 429.

Oseni, Umar A and Kadouf, Hunud Abia "The Discrimination Conundrum in the Appointment of Arbitrators in International Arbitration” (2012) 29 J Int'l Arb 519. 
Pillay, Mohan R "The Singapore Arbitration Regime and the UNCITRAL Model Law" (2004) 20 Arbitration International 355.

Platt, Rowan "The Appeal of Appeal Mechanisms inInternational Arbitration: Fairness over Finality?” (2013) 30 J Int'l Arb 531.

Raghavan, Vikram "Heightened Judicial Review of Arbitral Awards: Perspectives from the UNCITRAL Model Law and the English Arbitration Act of 1996 on some US Developments" (1998) 15 J Int'l Arb 103.

Scherer, Matthias "Introduction to the Case Law Section" (2007) 25 ASA Bulletin 750.

Varady, Tibor "On the Option of a Contractual Extension of Judicial Review of Arbitral Awards - Or: What is Actually Pro-Arbitration?” (2006) 56 Zbornik PFZ 455.

Wasco, Mark D "When Less is More: The International Split over Expanded Judicial Review in Arbitration” (2009) 62 Rutg L Rev 599.

Zell, Jeremy L "Discerning the Validity of Arbitration Agreements Containing Heightened Judicial Review Clauses after Hall Street Associations, L.L.C. v. Mattel, Inc.” 40 Loy U Chi LJ 959.

\section{LLM Papers}

Cunaj, Neida "Separability within the arbitration clause with special focus on U.S. jurisdictions" (LLM short thesis, Central European University, 2014). 